\title{
Regenerated Cellulose Products for Agricultural and Their Potential: A Review
}

\author{
Nur Amira Zainul Armir ${ }^{1}$, Amalia Zulkifli ${ }^{1}$, Shamini Gunaseelan ${ }^{1}$, Swarna Devi Palanivelu 1,2, \\ Kushairi Mohd Salleh 1,*, Muhamad Hafiz Che Othman ${ }^{2}$ (D) and Sarani Zakaria 1,*
}

1 Bioresources and Biorefinery Laboratory, Department of Applied Physics, Faculty of Science and Technology, University Kebangsaan Malaysia, Bangi 43600, Selangor, Malaysia; amirazainularmir@gmail.com (N.A.Z.A.); amaliaxzulkifli@gmail.com (A.Z.); shamini_88@hotmail.com (S.G.); P109377@siswa.ukm.edu.my (S.D.P.)

2 Department of Biological Sciences and Biotechnology, Faculty of Science and Technology, Universiti Kebangsaan Malaysia, Bangi 43600, Selangor, Malaysia; hafiz87@ukm.edu.my

* Correspondence: kushairisalleh@ukm.edu.my (K.M.S.); szakaria@ukm.edu.my (S.Z.)

check for updates

Citation: Zainul Armir, N.A.; Zulkifli, A.; Gunaseelan, S.;

Palanivelu, S.D.; Salleh, K.M.; Che Othman, M.H.; Zakaria, S. Regenerated Cellulose Products for Agricultural and Their Potential: A Review. Polymers 2021, 13, 3586. https://doi.org/10.3390/polym 13203586

Academic Editor: Carlo Santulli

Received: 17 August 2021

Accepted: 13 October 2021

Published: 18 October 202

Publisher's Note: MDPI stays neutral with regard to jurisdictional claims in published maps and institutional affiliations.

Copyright: (c) 2021 by the authors. Licensee MDPI, Basel, Switzerland. This article is an open access article distributed under the terms and conditions of the Creative Commons Attribution (CC BY) license (https:// creativecommons.org/licenses/by/ $4.0 /)$.
Abstract: Cellulose is one of the most abundant natural polymers with excellent biocompatibility, non-toxicity, flexibility, and renewable source. Regenerated cellulose (RC) products result from the dissolution-regeneration process risen from solvent and anti-solvent reagents, respectively. The regeneration process changes the cellulose chain conformation from cellulose I to cellulose II, leads the structure to have more amorphous regions with improved crystallinity, and inclines towards extensive modification on the RC products such as hydrogel, aerogel, cryogel, xerogel, fibers, membrane, and thin film. Recently, RC products are accentuated to be used in the agriculture field to develop future sustainable agriculture as alternatives to conventional agriculture systems. However, different solvent types and production techniques have great influences on the end properties of RC products. Besides, the fabrication of RC products from solely RC lacks excellent mechanical characteristics. Thus, the flexibility of RC has allowed it to be homogenously blended with other materials to enhance the final products' properties. This review will summarize the properties and preparation of potential RC-based products that reflect its application to replace soil the plantation medium, govern the release of the fertilizer, provide protection on crops and act as biosensors.

Keywords: fertilizer; mulching film; smart farming; soilless farming; water holding capacity

\section{Introduction}

The conventional agricultural or known as the industrial agriculture system, is regarded as non-sustainable subjected to how it is being governed and practiced. It is known as an agricultural system that uses synthetic fertilizers, herbicides, and pesticides and implements crop rotation [1]. Fertilizers are beneficial to improve the yield quantity; however, the long-term use of fertilizer has caused environmental non-point source (NPS) pollution [2]. Alongside, the conventional agricultural system is inexorably inefficient, subject to the chemicals' usage implications, soil degradation, large-scale plantations, crops' loss due to diseases and pests, less profitability, jeopardizing humans and crops' health $[1,3,4]$. The conventional agricultural practice also causes the degradation in water quality simultaneously uses up a huge amount of water. The water from any possible and suitable sources will be withdrawn and supplied to the irrigated crops, which concurrently hoisting the salt from soils and the contaminants elicited from the usage of fungicides, pesticides, and fertilizers [5]. The water from the irrigated croplands will flow back to the streams and, in conjunction with land loss due to urbanization and residential expansion, surge the water salinization, waterlogging, river waters' reduction, and loss of soil moisture [6,7]. Ensuring a sustainable world from the agriculture perspective has motivated the usage of sustainable and biodegradable materials as alternatives. 
The abundance of natural polysaccharides such as cellulose, pectin, alginate, starch, chitosan, xanthan gum is widely used as biopolymer materials and has benefited human beings for ages. Polysaccharides are also referred to as biopolymers that consist of approximately $>20$ to 60,000 monosaccharides units and are known as part of the plant cell wall, algae origin, animal origin, and bacterial production. The complex structure of polysaccharides has turned them into valuable elements on earth because they provide interesting interaction among themselves and other components such as protein [8]. The excellent characteristics of polysaccharides such as sustainable, cheap, and edible have made them popular biomaterials that are fabricated into coatings [9], films [10], hydrogels [11], and fibers [12]. Recently, the idea of using polysaccharide-inspired products for agriculture purposes has emerged as a modern way to overcome the issues related to conventional agriculture. The flexibility and precious properties such as possessing hydroxyl groups and hydrogen bonding between the hydroxyl groups made them water-soluble, rigid, high tensile strength, and viscous [8]. For instance, chitosan-films were employed in the plantation soil to control the soil microbiota, remediation, fertilizer-release system, and water absorbency [13]. Grafted sodium-alginate superabsorbent hydrogel with poly(acrylic) acid that exhibited the ability to release sodium humate was used to facilitate plant growth by accelerating the root development [14]. Plant-derived biomass such as lignocellulosic biomass has the potential to become a great resource as it offers a sustainable manner when processed into products $[15,16]$. Cellulose, a part of lignocellulosic biomass among lignin, hemicellulose, and cellulose derivatives, has shown great potential due to its advantageous properties that will be discussed in the following paragraphs.

Cellulose was first mentioned by a French chemist named Anselme Payen in 1838 when he obtained a 'residue' resulted from the acids and ammonia treatment on different parts of plant tissues as well as performing water extraction procedures [17]. It is a hydrophilic linear homopolymer that has a molecular formula of $\left(\mathrm{C}_{6} \mathrm{H}_{10} \mathrm{O}_{5}\right)_{n}$ and is made up of anhydroglucose (AGU) monomers or also known as D-glucose or glucans units [18]. AGU monomers are covalently bonded and formed the $\beta$-1,4-glycosidic bonds between $\mathrm{C} 1$ of one glucose ring and $\mathrm{C} 4$ of another glucose ring, stabilized by the bond formation between -OH and oxygen [19] (Figure 1). Cellulose remarkably unveils a range of versatile applications and is commercially marketed aside from its nature being an essential element for plant cell structure and development. It is notably employed in numerous applications such as medical and pharmaceutical, agricultural, cosmetics, sensor technology, water treatment, packaging, textiles, electrical devices, and food technology fields because it is low-cost, a renewable polymer, abundantly available, biodegradable, biocompatible, and harmless to the environment. Cellulose is regarded as one of the most important polymeric materials as it holds a unique structural architecture that brings specificity for the interaction with other molecules.

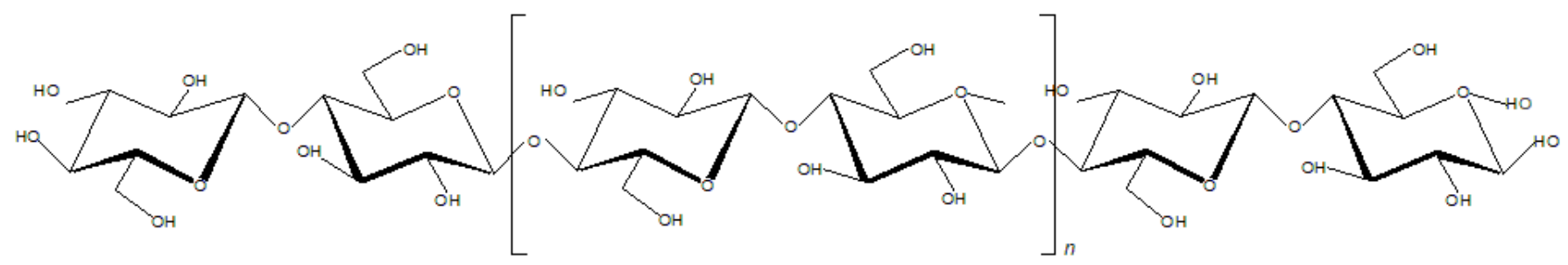

Figure 1. Structure of cellulose.

Cellulose I or known as native cellulose, exists as cellulose $\mathrm{I}_{\alpha}$ and $\mathrm{I}_{\beta}$ allomorphs that found the majority in higher plants for the former while algae and bacteria for the latter [20]. The hydrogen bonding that exists via intra- and intermolecular interaction along the repeating units of glycosidic- $\beta-1,4$-bonded-anyhydroglucose units is a major determinant of its behavior. Higher intermolecular and intramolecular hydrogen bonding dictate the properties of cellulose on account of a highly packed structure that eventually leads to higher crystallinity and thermal stability and stabilization and inhibits the thermal 
expansion, respectively $[20,21]$. The different plants will produce a different molecular weight of cellulose, whereby the molecular weight is manifested as one of the crucial factors that affect the cellulose solubility that eventually determines its solubility for application and development understanding [22]. The higher molecular weight of cellulose causes lower solubility of cellulose and vice versa based on higher molecular weight lowers the activation energy during cellulose dissolution. Another aspect that influences the solubility of cellulose is known as crystallinity that accounts for the crystalline area of cellulose; various measurements have been performed to determine the crystallinity index of cellulose [23]. Reduction in crystallinity of cellulose could increase the cellulose solubility; the structure of cellulose is not fully understood as its complex structure does not only revolve around crystallinity and amorphous aspects [23].

Native cellulose is challenging to be processed into desired products because of its insolubility in many solvents; thus, it needs to undergo powerful solvent treatment to break its supramolecular structure to dissolve it [24]. In recent years, the development of a deep understanding of cellulose regeneration drives the regenerated cellulose (RC) products to be used in the sustainable agriculture system, thus inspiring this review. This review aims to emphasize the applicability of RC products to be used in future agriculture systems and practice and to assist the readers and widen the attention for sustainable agriculture research. By definition, cellulose regeneration involves a structural transformation from cellulose I to cellulose II via two core techniques that are summarized as derivatizing and non-derivatizing processes [25]. The major fundamental difference between these two processes is the formation of modified cellulose preceding the regeneration process, where in this case, reflected by the derivatizing process while non-derivatizing solvents cause covalent modification is introduced by interfering with the inter- and intramolecular hydrogen molecular bonding. Correspond to this, while direct dissolution process employs physical intermolecular interactions (e.g., ionic liquids (ILs), NMMO, alkali-based solvents) then followed by precipitation with anti-solvent induction (e.g., coagulants, water) [25-29]. The regeneration is triggered to operate when the aqueous cellulose is energetically deprived for molecular dispersion and shifts the transient monomolecular sheets of hydrophobic interaction of glucopyranose rings of cellulose to the hydrogen-bonded that form cellulose II arrangement [30,31]. The regeneration is a counter-diffusion process between solvent and anti-solvents that reforms the inter- and intra-molecular hydrogen bonding in the cellulose structure [12].

The derivatizing process allows the formation of cellulose derivatives that give intermediate compounds such as 'unstable' ether-, ester-, intermediate acetal- upon dissolving in derivatizing solvents such as fluoroacetic acid, formate acid, dimethylsulfoxide (DMSO), and dimethylformamide (DMF) [32]. A non-derivatizing solvent such as alkali/urea aqueous system that is commonly used, cellulose is dissolved as the alkali hydrates, and urea complexes formation has contributed to this system [32]. A new hydrogen bond is formed when alkali hydrates tend to join the hydroxyl groups of cellulose. Then, the formation of inclusion complexes occurs due to the interaction between urea and alkali ions that enables the permeation of water molecules and alkali hydrates into the crystals of cellulose. It aids the process of dissolving subsequently. Next, for non-aqueous systems in this category, as an example, ILs are commonly used because they offer various advantages such as environmental-friendly solvent and possess excellent thermal and chemical stability [33]. The conformational change from cellulose I to cellulose II was observed upon dissolving cellulose in ILs that is triggered by anion and superbase cations of ILs bonded to the polar and non-polar domains of cellulose by Van der Waals forces, respectively [34]. The exceptional ability to dissolve cellulose by ILs is due to the lower degree of polymerization of cellulose imposed by easy aggregation of cellulose chains and, subsequently, regenerated in anti-solvent system [35]. Despite outstanding properties and abilities of ILs producing RC, a derivatizing aqueous system using alkali/urea solvent is preferred because some inflicted disadvantages of ILs such as expensive as well as separation and purification process to obtain RC [36]. The examples of cellulose solvents and their mechanism are summarized in Table 1. 
Table 1. Cellulose solvents and their action mechanism.

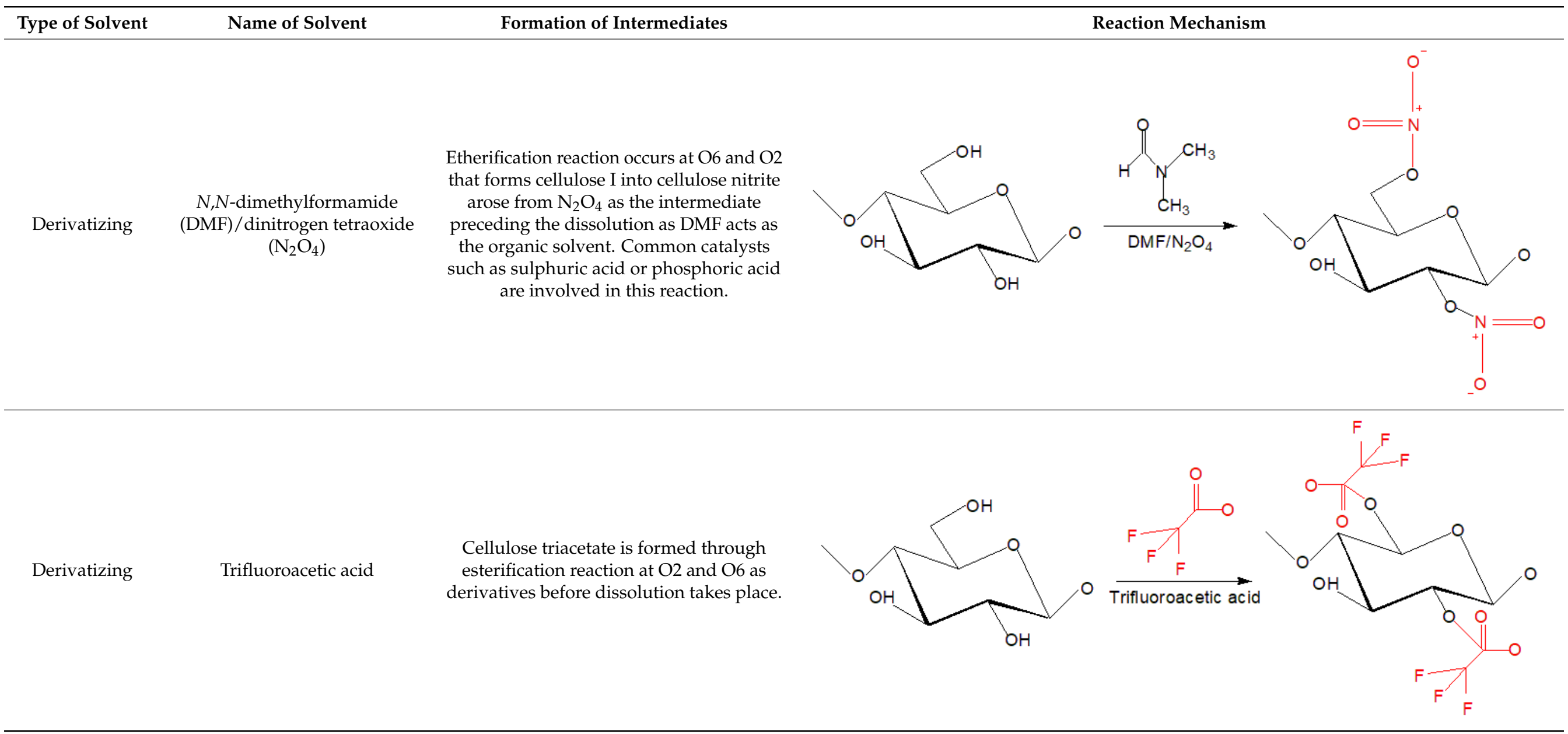


Table 1. Cont.

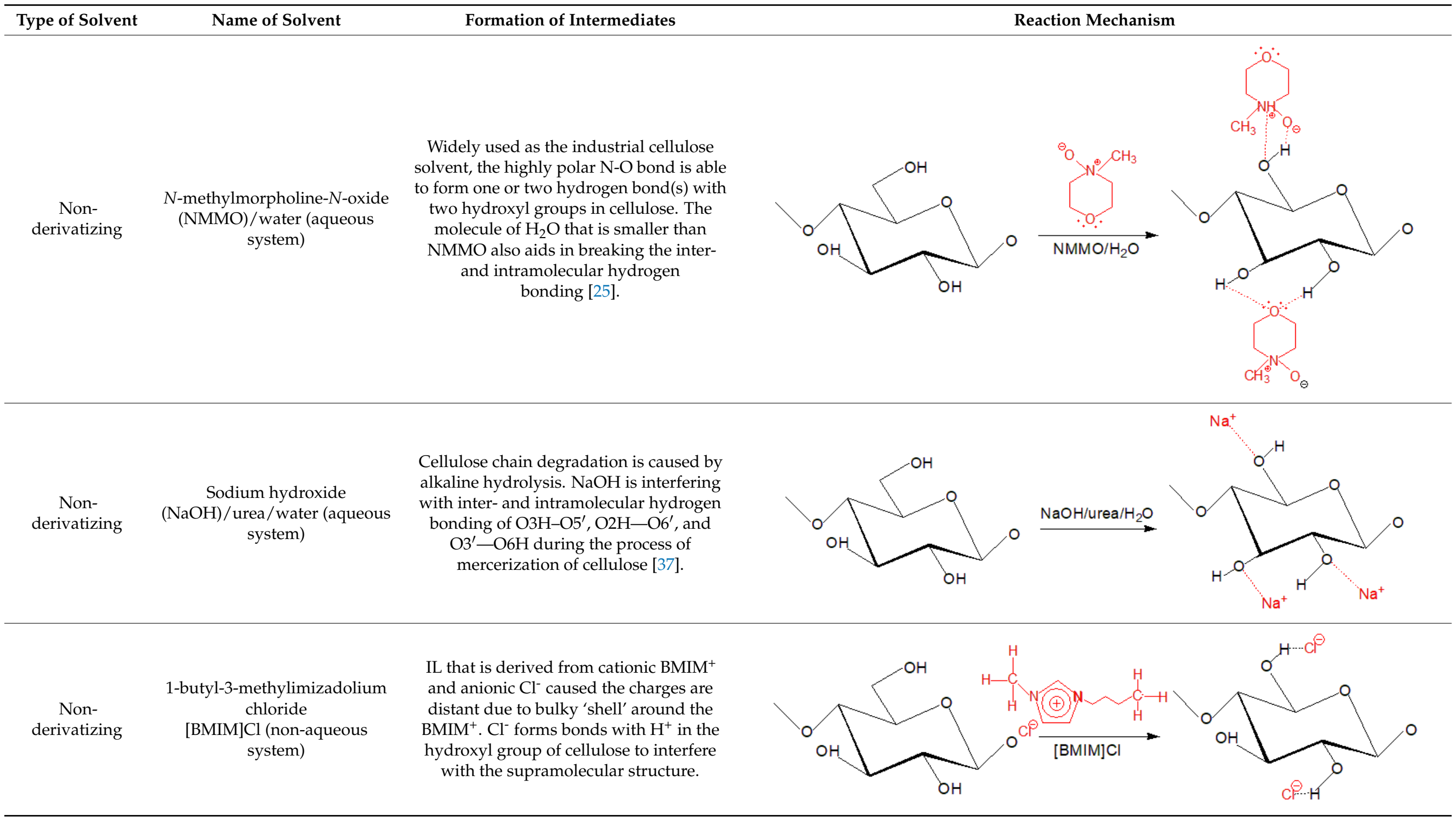


The dissolution of cellulose I transforms the cellulose allomorph into cellulose II that is known as the most stable allormorph of cellulose, as illustrated in Figure 2. In terms of structure orientation, cellulose I and II are observed to be in parallel and antiparallel orientation, respectively. The difference between cellulose I and II in term of their inter- and intramolecular hydrogen bonding are shown if Figure 3. Cellulose I has inter- and intramolecular hydrogen bonding at $\mathrm{O} 3 \mathrm{H}-\mathrm{O}^{\prime}$ and $\mathrm{O} 6 \mathrm{H}-\mathrm{O}^{\prime}$, respectively, while $\mathrm{O} 2 \mathrm{H}-\mathrm{O}^{\prime}$ (which also linked in cellulose I) and $\mathrm{O} 6 \mathrm{H}-\mathrm{O} 2^{\prime}$ are reported to be intra- and intermolecular hydrogen bonding for cellulose II [38]. Cellulose II has a low degree of polymerization, low elastic modulus, high polydispersity, and reduced crystallinity that causes its decomposition at a lower temperature as compared to cellulose I [26,39]. Although the crystallinity of regenerated cellulose is dictated by its dissolving solvent, studies have shown a reduction in crystallinity of regenerated cellulose. The transformation of cellulose I to regenerated cellulose can be observed via X-ray diffractogram, infrared profile, ${ }^{13} \mathrm{C}$ nuclear magnetic radioactive (NMR) spectra, and thermal analyses. The aforementioned examples about the transformation characterization of cellulose I to cellulose II (or RC) are listed in Table 2. The regeneration of cellulose, which is a favored process, has been widely explored due to the crystallinity improvisations it brings on the properties of cellulose [40,41].

\section{Native cellulose}
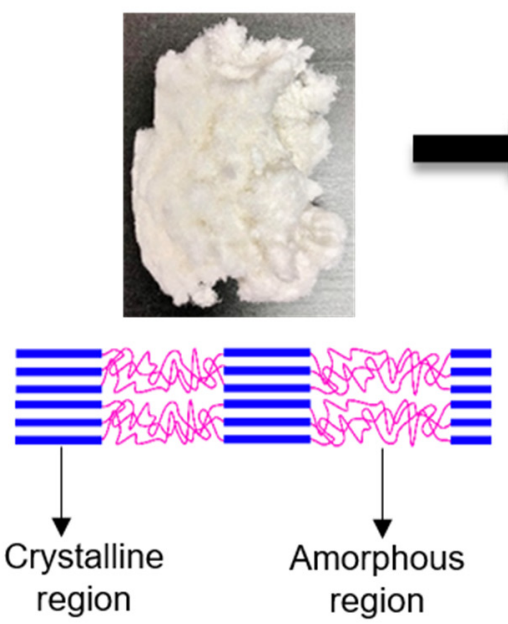
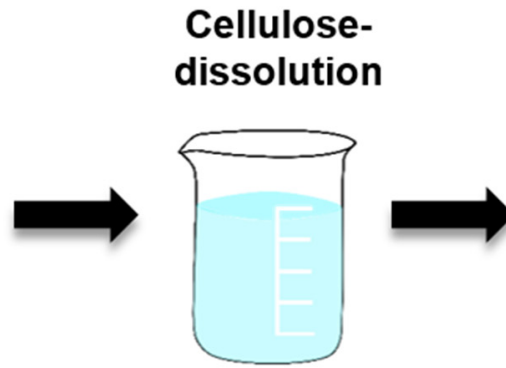

Celluloseregeneration

Figure 2. The dissolution-regeneration of native cellulose. 
Table 2. The characterization of transformation of cellulose I to cellulose II via XRD, Fourier-transform infrared spectroscopy (FTIR), ${ }^{13} \mathrm{C}$ NMR, and Raman spectroscopy.

\begin{tabular}{|c|c|c|c|c|}
\hline Characterization & Method & Cellulose I & Cellulose II & Explanation \\
\hline \multirow[t]{3}{*}{ Crystalline structure } & XRD & $\begin{array}{c}\text { Crystalline interplanar }(1-10),(110), \\
(012),(200),(004) \text { Miller indices and } \\
\text { amorphous are represented by } 12.3^{\circ}, \\
16.5^{\circ}, 20.4^{\circ}, 22.6^{\circ}, 34.4^{\circ} \text { and near } \\
20.5^{\circ}[42,43] .\end{array}$ & $\begin{array}{l}\text { Crystalline interplanar of }(1-10),(110),(020) \\
\text { and amorphous shown in XRD profile of } \\
\text { cellulose II that are represented by } \sim 12.3^{\circ}, \\
\sim 20.1^{\circ}, \sim 22.0^{\circ} \text { and } \sim 20.5^{\circ} \text {. Overlap }(110) \text { and } \\
(020) \text { peaks might be attributable for more } \\
\text { amorphous RC subjected to type and } \\
\text { parameter of cellulose solvent }[42,44] .\end{array}$ & \multirow[t]{2}{*}{$\begin{array}{l}\text { The loss of peak and generation of the } \\
\text { crystalline peaks are due to the } \\
\text { rebuilding of hydrogen bonding [42]. }\end{array}$} \\
\hline & FTIR & $\begin{array}{c}1428 \mathrm{~cm}^{-1} \text { peak is considered to be } \\
\text { the crystalline region }[45,46]\end{array}$ & The $1428 \mathrm{~cm}^{-1}$ peak is lost [42]. & \\
\hline & $\mathrm{C}_{13}$ CP-MAS NMR & $\begin{array}{l}\text { Singlet signal } 100-110 \mathrm{ppm}, 96 \mathrm{ppm}, \\
\text { and } 60-70 \mathrm{ppm} \text { correspond to } C_{1}, C_{1} \\
\text { (reducing end), and } C_{6}[47]\end{array}$ & $\begin{array}{l}\text { Extra small shoulder peak at } 107 \mathrm{ppm} \text {, peak of } \\
\mathrm{C}_{1} \text { reducing end at } 96 \mathrm{ppm} \text { is not detected, and } \\
\mathrm{C}_{6} \text { peak is shifted [47] }\end{array}$ & $\begin{array}{l}\mathrm{C}_{6} \text { peak confirms the crystalline } \\
\text { structure of cellulose, where, when it is } \\
\text { not detected in cellulose II, it is shown } \\
\text { that cellulose has a lower degree of } \\
\text { polymerization compared to cellulose I. }\end{array}$ \\
\hline Chemical structure & FTIR & $\begin{array}{l}\text { O-H stretching, } \mathrm{C}-\mathrm{H}_{2} \text { stretching, } \\
\text { and } \mathrm{C}-\mathrm{O}-\mathrm{C} \text { pyranose ring vibrations } \\
\text { at } 3700-3300 \mathrm{~cm}^{-1}, 2900 \mathrm{~cm}^{-1} \text {, and } \\
1163 \mathrm{~cm}^{-1}[42,48]\end{array}$ & $\begin{array}{l}\mathrm{O}-\mathrm{H} \text { stretching, } \mathrm{C}-\mathrm{H}_{2} \text { stretching, and C-O-C } \\
\text { pyranose ring vibrations at } 3345-3393 \mathrm{~cm}^{-1} \\
\text { (shift to a higher number), } 2921 \mathrm{~cm}^{-1} \text { (shift to a } \\
\text { higher number and } 1157 \mathrm{~cm}^{-1} \text { (shift to a lower } \\
\text { number) [42]. }\end{array}$ & $\begin{array}{l}\text { Transformation of cellulose I to cellulose } \\
\text { II has occurred. O-H peak is shifted to a } \\
\text { lower number is due to more -OH are } \\
\text { created and more water adsorption [48] }\end{array}$ \\
\hline \multirow[t]{2}{*}{ Decomposition } & $\begin{array}{c}\text { Thermogravimetric analysis } \\
\text { (TGA) }\end{array}$ & $\begin{array}{l}\mathrm{T}_{\text {onset }} \text { that refers to the removal of } \\
\text { water is higher while the } \\
\text { decomposition of cellulose reflected } \\
\text { by } \mathrm{T}_{\max } \text { is lower }[42,49,50] .\end{array}$ & $\begin{array}{l}\text { In contrast, } \mathrm{T}_{\text {onset }} \text { that refers to the removal of } \\
\text { water is lower while the decomposition of } \\
\text { cellulose reflected by } \mathrm{T}_{\max } \text { is higher }[42,49,50] \text {. }\end{array}$ & $\begin{array}{l}\text { The lower } \mathrm{T}_{\text {onset }} \text { is due to the lower } \\
\text { crystallinity recorded in cellulose II. } \\
\text { Cellulose II is more thermally stable } \\
\text { than cellulose I is due to its more } \\
\text { ordered antiparallel chain that is } \\
\text { regenerated after dissolution. }\end{array}$ \\
\hline & $\begin{array}{l}\text { Differential scanning } \\
\text { calorimetry (DSC) }\end{array}$ & Has higher $\mathrm{T}_{\mathrm{g}}=64^{\circ} \mathrm{C}[51]$ & Lower $\mathrm{T}_{\mathrm{g}}=62^{\circ} \mathrm{C}[51]$ & More $-\mathrm{OH}$ surface groups on cellulose \\
\hline
\end{tabular}



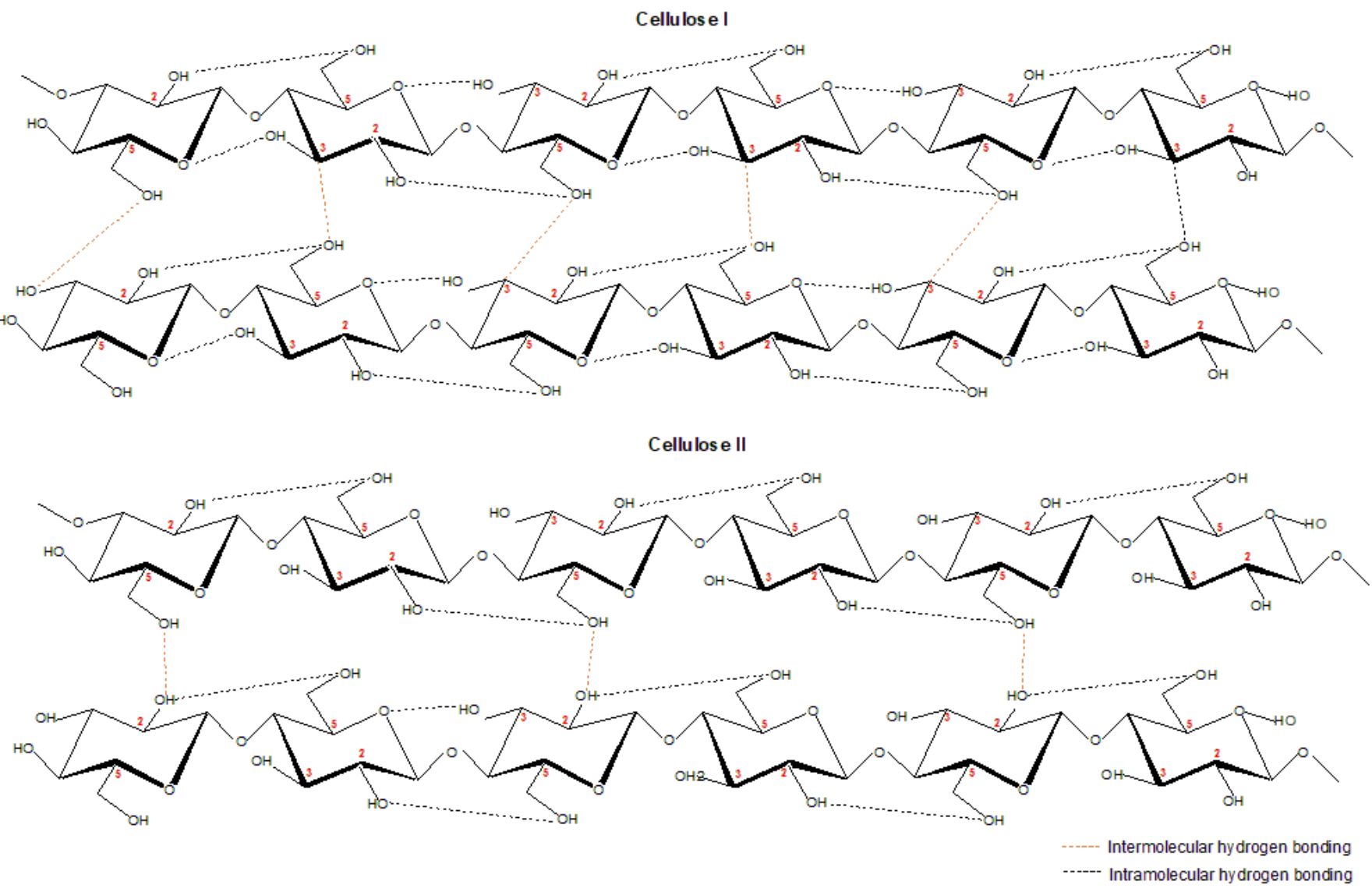

Figure 3. The structure of cellulose I and cellulose II.

\section{Regenerated Cellulose Products}

\subsection{Hydrogel, Aerogel, Cryogel, and Xerogel}

Generally, hydrogel is a three-dimensional cross-linked polymeric network and able to absorb and retain a large volume of water due to extensive hydrophilic chains of the polymers employed such as $-\mathrm{OH},-\mathrm{NH}_{2},-\mathrm{COOH}$, and $-\mathrm{SO}_{3} \mathrm{H}$ that is associated with the polymeric backbones [52-54]. Physical cross-linking is formed via various mechanisms include ionic interaction, hydrophobic interaction, hydrogen bonding, ultrasonic induction, and crystallization or classified as non-covalent interactions [55-57]. The chemical crosslinking occurs as the chain-growth polymerization, irradiation, covalent bonding, stepgrowth polymerization 'click', and chemistry that induce the covalent interaction. The cross-linking actions determine the properties of a hydrogel, such as a brittle and rigid hydrogel is formed via higher cross-linking density, and low cross-linking density manifests a good elasticity hydrogel. Some other products can be extended from hydrogel to broaden the applications by varying the drying method or liquid removal from the hydrogel afterward (Table 3).

The RC hydrogel is a sustainable initiative due to its biocompatibility and biodegradability has been employed in myriad applications such as controlled- and slow-release of materials, medium to retain water, and bio-sensors that are appropriate for agricultural purposes [58]. RC hydrogel can be produced via facile manners as it is compatible with a wide range of polar and non-polar solvents as well as compatible with other materials to increase the fabricated products [59]. The process of producing RC hydrogel includes few steps; (i) cellulose dissolution, (ii) regeneration of cellulose solvent in coagulant, (iii) crosslinking, and (iv) drying (for aerogel, cryogel, and xerogel productions). Besides, it is flexible to be physically or chemically crosslinked, as reported in numerous studies. Regardless of the 
excellent properties an RC can provide, it is unstable to form a product alone due to interand intramolecular hydrogen bonding, while its excellent porosity can cause shrinkage during regeneration, fragile, and higher elongation at break [60]. Thus, other materials will be incorporated into the RC system in order to increase the lack of characteristics. Furthermore, as mentioned previously, the crosslinking method also plays a crucial role in determining the end result of the fabricated RC hydrogel. It is flexible with either chemical or physical crosslinking (or both) approach, the properties of RC hydrogel could be adjusted accordingly, such as poor mechanical strength and toughness that limit its application [61]. For instance, a dual crosslinking network (chemically crosslinked by cinnamoyl-gelatin and further UV-photocrosslinked) that is applied to RC hydrogel with gelatin composite (dissolve together in 1-ethyl-3-methylimidazolium diethyl phosphate IL (EMIM)(DEP)) has better properties rather than chemically-crosslink the hydrogel only [59]. This dual crosslinking RC hydrogel has a higher compressive modulus and excellent water retention compared to hydrogel without photocrosslinking. In another study, single network (SN) RC hydrogel (ECH-crosslinked) and double network (DN) RC hydrogel (epichlorohydrin $(\mathrm{ECH})$ and polyacrylamide (PAAm)-crosslinked) is compared [61] (Figure 4). According to this, the thermal stability, transparency, compression test, and elastic modulus increases on DN RC hydrogel. This study highlights the flexibility of RC in crosslinking as it has large -OH groups and the intermolecular hydrogen bonding forms chemical bonds with ECH that create spaces between them. The spaces perpendicularly increase with a higher ratio of ECH to cellulose, and this is an excellent property to develop a porous network of large water absorption; however, the mechanical strength and stiffness will lowered. Besides, the addition of PAAm into the system has created many crosslinking points and increase the mechanical and compression strength of RC hydrogel that in the same time reflects the flexibility of RC to form a homogenously blend with other materials. Apart from that, ionogel is fabricated from dissolution cellulose in IL and forming gel due to strong hydrogen bonds between regenerated cellulose and IL during regeneration process [62]. Ionogel is appeared to be yellowish due to dissolved cellulose and eventually develop into colourless gel during swelling [63]. The properties of ionogels include electroactive, better transparency and higher compressive strength compared to hydrogel.

The porosity of RC hydrogel could be changed amid the liquid removal or drying, which then produce aerogel, cryogel, and xerogel that depend on the desired interests. The supercritical- and freeze-drying of RC aerogel can retain the solid nano-porous structure; however, it gives fibrous aggregation uneven pore and lamellar aggregation as well as huge structure collapse [64,65]. The freeze-drying technique also leaves RC aerogel, cryogel, or xerogel to have points of the dense region at the RC rich regions because the ice crystals that form at these particular regions (during freezing) assemble into aligned columns and later will be squeezed by drying [59]. Then, they construct the RC fibrils to form an oriented cellulose scaffold. Other materials are incorporated with the RC aerogel production, such as silica, to prevent its structure collapse because the RC-rich regions will shrink after dried [66]. On the other hand, Ciocalu et al. (2016) had conducted a study to compare the type of crosslinking effect on hydrogel and cryogel from RC [67]. Chemical crosslinking by using $\mathrm{ECH}$ has shown less shrinkage on the RC products because the epoxy ring of $\mathrm{ECH}$ is actively reacting with the extensive - $\mathrm{OH}$ groups in the $\mathrm{RC}$ and is more homogenous; thus, it provides better swelling properties for both RC cryogel and hydrogel. This study also highlights the 'hornification' phenomenon during the transition of RC hydrogel to RC cryogel that resulted in less swelling in RC cryogel despite having better humidity adsorption. Limited studies of RC xerogel have been reported due to extreme volume shrinkage upon drying; however, research application is more inclined towards cellulosexerogel that is derived from cellulose nanofiber (CNF) [68]. Buchtova and Budtova (2016) had shown that RC xerogel that is produced from low-vacuum evaporative drying on pore walls has very high volume shrinkage due to strong capillary pressure alongside densification due to large $-\mathrm{OH}$ in the $\mathrm{RC}$. 


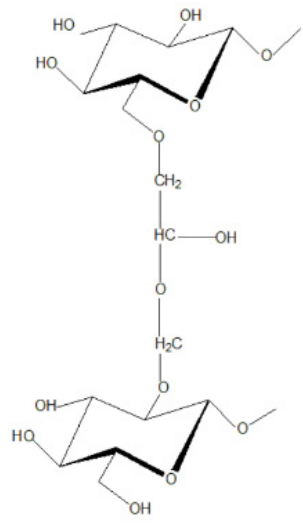

ECH-RC hydrogel (Single network)

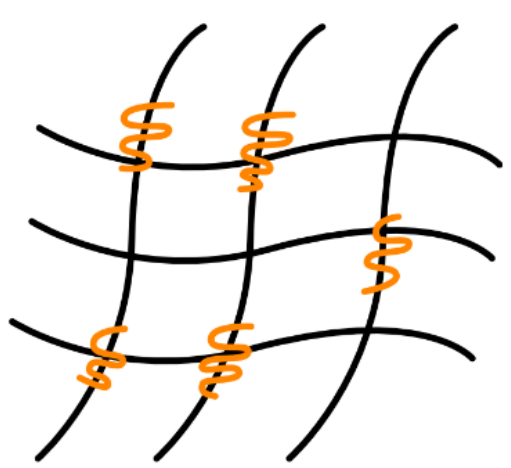

$\mathrm{ECH}-\mathrm{RC}$ hydrogel (Single network)

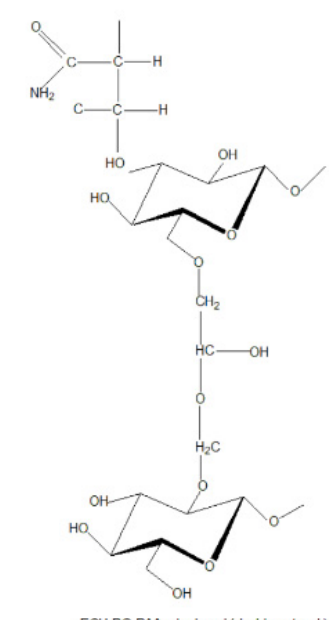

ECH-RC-PAAm hydrogel (double network

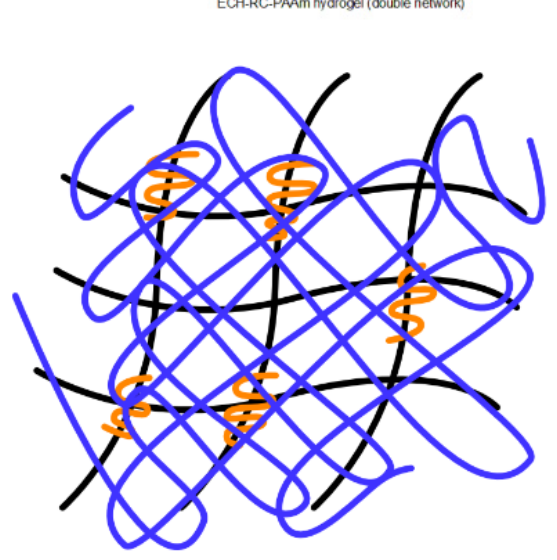

ECH-RC-PAAm hydrogel

(Double network)

Figure 4. Single and double hydrogel network modified by PAAm.

Table 3. Extended products from hydrogel fabrication.

\begin{tabular}{cccc}
\hline Type of Product & Method of Production & Properties & Appearance \\
\hline Aerogel & $\begin{array}{c}\text { First developed by Kristler in } \\
\text { the 1930s performed by a } \\
\text { supercritical drying to remove } \\
\text { liquid from hydrogel [69] }\end{array}$ & $\begin{array}{c}\text { Low density, large surface area, excellent } \\
\text { mechanical properties, and high porosity. } \\
\text { Sometimes, brittle aerogel is produced } \\
\text { due to the drying technique applied. } \\
\text { Commonly as an adsorption material. }\end{array}$ & White, opaque, lightweight \\
Cryogel & $\begin{array}{c}\text { Hydrogel is frozen and } \\
\text { lyophilizes at very low } \\
\text { temperature to remove liquid }\end{array}$ & $\begin{array}{c}\text { Lightweight and low density. Compact } \\
\text { structure and large porosity depend on } \\
\text { freezing temperature and ice crystals } \\
\text { formation during freezing. }\end{array}$ & White, opaque, lightweight \\
Xerogel & $\begin{array}{c}\text { Low-evaporative or vacuum } \\
\text { drying of hydrogel and } \\
\text { subsequently forming a thin } \\
\text { porous film with extreme } \\
\text { shrinkage [70]. }\end{array}$ & $\begin{array}{c}\text { Mimicking aerogel but improved in } \\
\text { brittleness characteristic that is }\end{array}$ & Yellowish, shrunk, translucent \\
commonly generated from aerogel [68]. \\
Dense, compact, and very low porosity.
\end{tabular}




\subsection{Fibers}

Fibers are defined as thin thread structures made from natural or man-made materials. Fibers are divided into three primary groups; (1) natural fibers, (2) natural/man-made, and (3) man-made fibers. The natural fibers are cheap, low density, biodegradability, abundant, and have renewability properties [71,72]. They are classified into three main types such as plant fibers, which are known as cellulosic or lignocellulosic fibers, animal fibers, and mineral fibers. There are six groups under plant fibers such as leaf, bast or stem fibers, fruit or seed fibers, wood, stalk, and grass or reeds [73]. RC is categorized under the natural/man-made group. Three types of RC fibers such as modal, viscose, and lyocell. Meanwhile, man-made fibers are synthetic fibers like carbon, glass, and aramid [74].

Synthetic fibers have been commonly used in the various industries especially in the textile industry, but it offers a serious threat to the environment such as water pollution, and the source of synthetic fibers is made from petroleum. Water pollution occurs due to the procedure of making synthetic fiber like washing, bleaching, and dyeing that release various unwanted chemicals to the environment [75]. Hence, it is not preferable to fiber compared to the naturally made fiber, RC fiber which is biodegradable and safe to the environment. In addition, the source of raw material for making RC fiber is inexpensive, abundant, and has become the best alternative for substituting conventional synthetic fiber. Nevertheless, RC fiber still has drawbacks, such as the mechanical properties are poor when it is used alone. For that reason, there are few studies have been done on the enhancement of properties of RC fiber to use them in various applications [76]. Meanwhile, $\mathrm{RC}$ fiber also can be incorporated as reinforcement in the green composites [77,78]. The advantages of RC fiber compared to synthetic fiber as reinforcement are delicate and low density [79].

There are few methods for producing high-quality RC fibers by dissolution and regeneration process [80]. Usually, the fibers will be prepared via the spinning method [34,81,82]. The RC fiber was obtained by coagulation process in which equipment consists of a polymer cylinder reservoir, spinneret, coagulation bath, and rotating fiber collector, as illustrated in Figure 5. The wet spinning technique is one of the common methods used in the formation of RC fiber. The fibers are made by extruding cellulose solution through a spinneret into the acid bath for coagulation. Next, the fibers are cleansed by utilizing hot water first and distilled water to eliminate the salts obtained during the coagulation process. The produced RC fiber is then dried at the ambient temperature [32,83]. Briefly, RC fibers can be employed in the agriculture industry due to the chemicals used for the production are low cost, non-toxicity, and environmentally friendly [83,84].

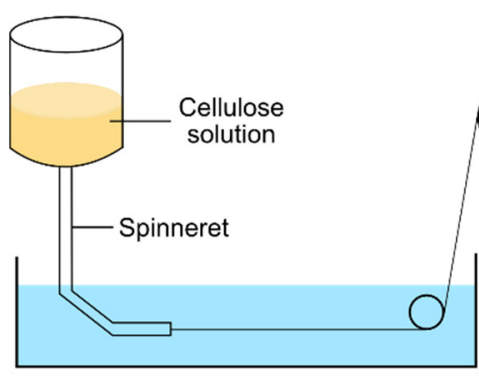

Coagulation bath

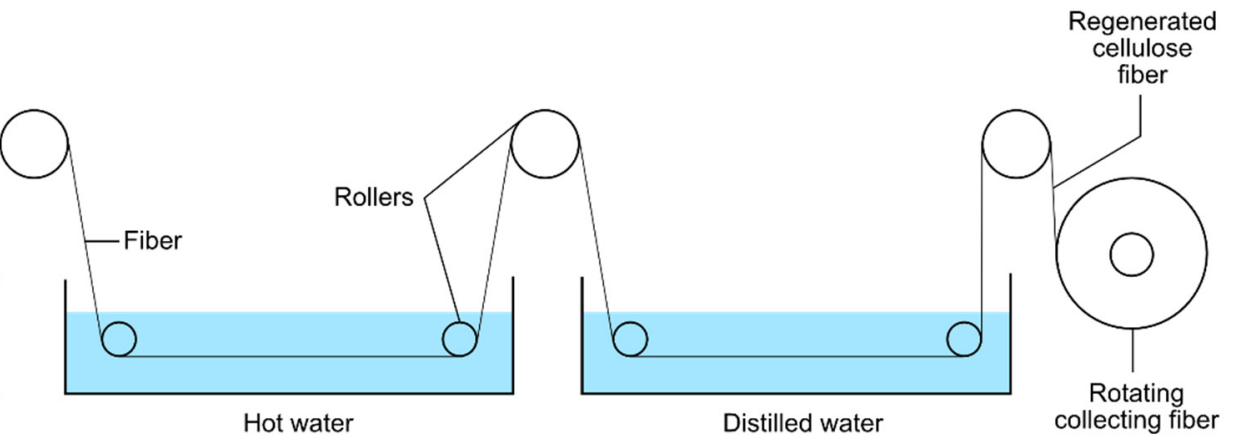

Figure 5. Schematic diagram of basic RC fiber processing. 
Different solvents systems could affect the properties of RC fibers. There are diverse inventions of solvent systems in the past research. Hence, few studies of RC fiber dissolve in different types of solvent and coagulation baths are tabulated in Table 4. Each solvent system could affect the final products of RC fiber and have its advantages. For instance, ionic liquids have been proven safe to be used, simple and these solvents enhance the tensile strength of RC fiber [85]. The rheological behavior of most cellulose solutions is the shear-thinning property and non-Newtonian flow [86]. This is due to the increasing amount of cellulose affect the molecular chains of cellulose to be increased [87]. The parameters of draw ratio, spinning dopes, and fiber spinning can be tailored to get the best structural and mechanical properties of RC fiber. According to Ma and the co-workers, the morphology of RC fiber will be irregular and severe grooves of the surface when the draw ratio is low. Meanwhile, the RC fiber form at a high draw ratio will obtain a smooth surface with a round structure [88]. Yang et al. have been discussed that the higher tensile strength has been contributed by the high degree of crystallinity and low orientation of microvoids [83]. The longevity of RC fibers is important to use for a long time. Therefore, the biodegradation of RC fibers should be monitored, and it is suggested to utilize the biodegradable polymer and combine it with cellulose to form composite RC fiber.

Table 4. Properties of RC fiber in different types of solvents.

\begin{tabular}{|c|c|c|c|c|}
\hline Source of Cellulose & Type of Solvent & $\begin{array}{c}\text { Coagulation } \\
\text { Bath }\end{array}$ & Properties of RC Fibers & References \\
\hline Sugarcane Bagasse & $\begin{array}{l}\mathrm{N} \text {-methylmorpholine- } \\
\mathrm{N} \text {-oxide (NMMO) } \\
\text { hydrate }\end{array}$ & Ethanol & $\begin{array}{l}\text { Morphology: Higher fibrillation } \\
\text { Elongation at break: } 2 \% \\
\text { Tensile strength: } 530 \mathrm{MPa}\end{array}$ & [89] \\
\hline Dissolving pulp & $\begin{array}{l}\text { 1-butyl-3- } \\
\text { methylimidazolium } \\
\text { chloride (BMIMCl) }\end{array}$ & Water & $\begin{array}{c}\text { Morphology: No obvious voids and } \\
\text { intact surface with dense inner } \\
\text { structure } \\
\text { Elongation at break: } 6.6 \% \\
\text { Tensile strength: } 808 \mathrm{MPa}\end{array}$ & [90] \\
\hline Wood pulp & $\begin{array}{c}\text { 1-butyl-3- } \\
\text { methylimidazolium } \\
\text { acetate } \\
\text { ((Bmim)OAc)/dimethyl } \\
\text { sulfoxide (DMSO) }\end{array}$ & Water & $\begin{array}{l}\text { Morphology: Irregular, serrated } \\
\text { cross-section and severe grooves of } \\
\text { the surface } \\
\text { Elongation at break: } 5.4 \% \\
\text { Tensile strength: } 22.5 \mathrm{cN} / \text { tex }\end{array}$ & [88] \\
\hline Soft wood pulp & $\begin{array}{l}\text { Tetrabutylammonium } \\
\text { acetate } \\
\text { (TBAA)/dimethyl } \\
\text { sulfoxide (DMSO) }\end{array}$ & Acid & $\begin{array}{c}\text { Morphology: Smooth surface as round } \\
\text { and compact structure } \\
\text { Elongation at break: } 9.7 \% \\
\text { Tensile strength: } 2.15 \mathrm{cN} / \mathrm{dtex}\end{array}$ & [87] \\
\hline Cotton linters & $\mathrm{NaOH} /$ thiourea/urea & Acid & $\begin{array}{l}\text { Morphology: Smooth surface and } \\
\text { circular cross-section with } \\
\text { homogeneous and denser structure } \\
\text { Elongation at break: } 9.47 \% \\
\text { Tensile strenghth: } 2.22 \mathrm{cN} / \mathrm{dtex}\end{array}$ & [83] \\
\hline
\end{tabular}




\subsection{Membrane and Thin Film}

$\mathrm{RC}$ membrane is also obtained via the dissolution-regeneration process and subsequent casting in coagulant and resulted in a microporous structure with hundreds of nanometers in diameter [91,92]. The fabrication of RC membrane and RC thin film is performed by the casting of the dissolved cellulose solution on a glass plate to form a uniform thickness of the membrane, whereas immersion of the glass plate in coagulant creates the regeneration of cellulose [93-95]. The research interest on RC membrane and a thin film is vastly due to its excellent mechanical properties, and high porosity has enabled it to be widely employed in the agricultural sector [96,97]. The ability to tailor the characteristics of membrane aids in a material with better resistance to severe cleaning mechanisms such as oil contamination treatments in wastewater treatment in which the treated water can be applied for irrigation purposes [98]. The inadequacy of clean water is a widely debated issue in the status quo due to the growing worldwide population, especially in continents such as Asia and Africa [99]. The agriculture sector will remain the largest user of clean water since it utilizes about 70\% of global water for irrigation purposes [100]. A similar concept can be utilized during the application of cellulose membrane to separate oil from water, and this is one of the reliable measures to produce clean water, which can then be further utilized in agriculture.

Traditionally, contaminated wastewater is cleaned up through some techniques such as flotation, adsorption, or coagulation that is gravity-driven for oil/water separation [101]. However, these chemical and energy-intensive techniques are expensive and have invited secondary pollution due to toxic and corrosive materials used [102]. Besides, the practicality of these techniques only lies in oil droplets' size $<150 \mu \mathrm{m}$ or between 20 to $150 \mu \mathrm{m}$ for unstable oil droplets [101]. Concerning environmental pollution, the highly porous, hydrophilic, and oleophobic in water atmosphere cellulose is utilized as the oil/water separation-RC membrane [103]. The wettability under oil/water is essential in oil/water separation membranes due to its application in a wet state. The RC membranes also demonstrated high oleophilic properties when they formed a continuous layer of oil on the membrane's surface and behaving as a water repellent, which is essential to separate the oil/water emulsions. Similarly, Fan et al. (2018) fabricated an all RC composite membrane with citric acid (CA) as the cross-linker and subjected it through an emulsion of oil/water [104]. They found out that the carboxyl groups from CA and hydroxyl groups from RC formed a hydrated sheath via capturing water molecules that gave a cushion-like behavior to the membrane that prevents direct contact with oil (Figure 6). Due to the low oil adhesion of the membrane, the oil droplets were able to roll on the membrane's surface and became bigger due to the coalescence effect. The membrane achieved the removal of oil from water through the mechanism of filtration. The mechanism in both membranes fabricated by Fan et al. (2018) and Yagoub et al. (2019) was different, whereby the former utilized the concept of wettability and the latter utilized the concept of flotation and filtration $[104,105]$. The utilization of cellulose membrane in producing clean water can be further utilized in areas that require clean water for irrigation purposes. 


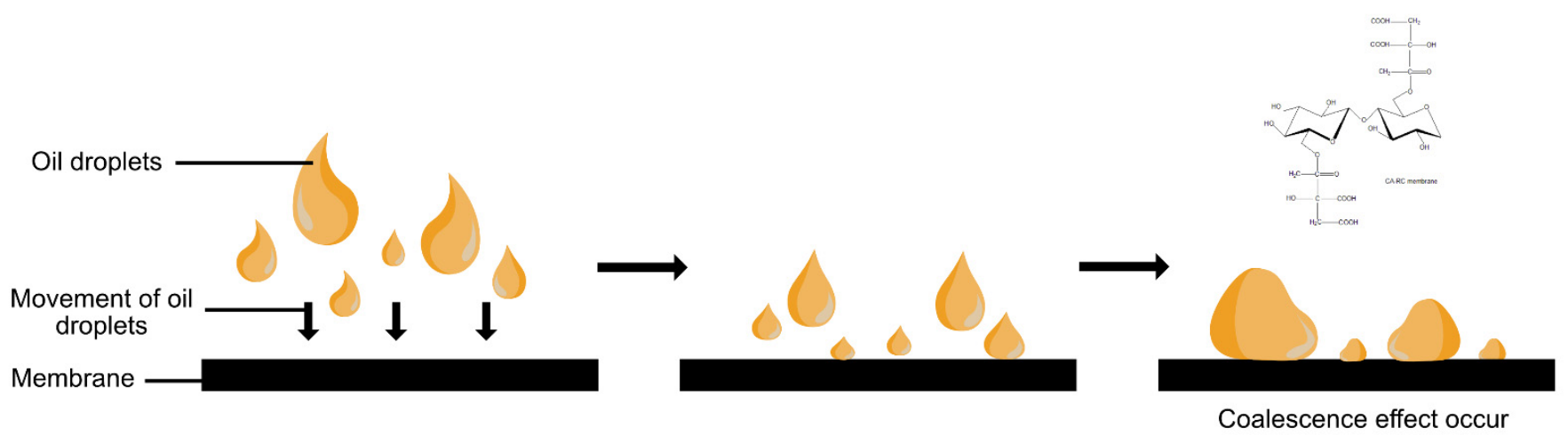

Figure 6. Formation of the hydrated sheath on RC membrane with CA crosslinking.

3. The Potential Applications of Regenerated Cellulose Products for Agriculture

\subsection{Excellent Water Conserver for Plantation Media}

Several soilless agricultural systems have been introduced to this day, such as aeroponic, hydroponic, nutrient film technique (NFT), floating system, wicking system, drip technique, flow system, and aquaponics [106]. Soilless agricultural or soilless farming brings the ability to reduce environmental damage and a reasonable opportunity for the world to achieve sustainable agriculture [107-109]. In respect to this, few aspects that construct the soilless system cultivation make it promising through nutrients recycling to reduce the fertilizers' run-off and vertical or stacked plantation to reduce the plantation's space besides being soil-free [110]. Recently, the soilless plantation system that uses RC products has drawn much attention due to its promising applications for agriculture purposes. With many interventions that have been made in the past decades to rescue future generations' needs, especially in the perspective of agriculture, growing soilless culture are being developed and implemented. Until these days, improvement is continuously pursued. The revolution of RC products (e.g., hydrogel-based products) that possess amphipathic properties, excellent biocompatibility that can be incorporated with diverse materials as well as biodegradable at a certain period have always encouraged researchers to ameliorate the intended products. RC hydrogel has shown much significance in the agriculture field, such as (1) aiding in moisture preservation that is exceptional for arid places and countries that undergo winter season as well as reducing water consumption in the conventional irrigation system, (2) a medium that can be loaded with nutrients and accommodate with controlled-release behavior mechanism, (3) maintaining and increasing soil health by reducing soil erosion and binding the loose soil to increase the soil grip for better root latching [111]. Few examples are listed in Table 5 . 
Table 5. Example of the RC products in the agricultural potential uses.

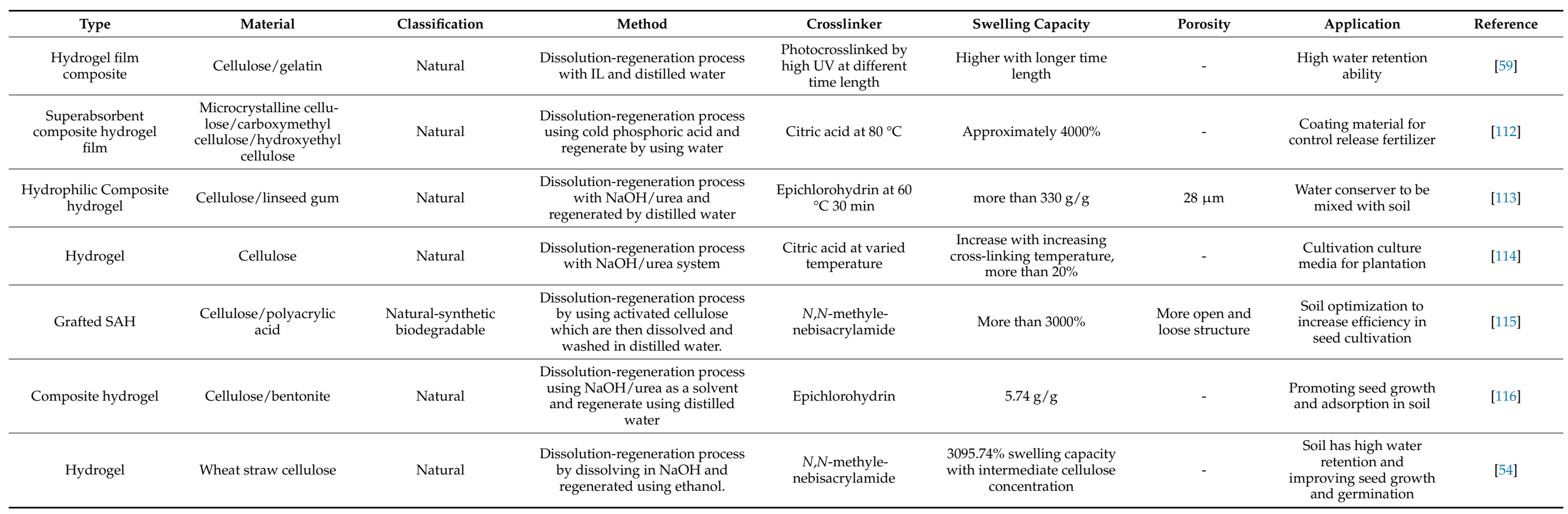


Increasing demand for food commodities is causing the expansion of agriculture and inciting greater water consumption due to conventional agriculture that uses irrigation systems. This circumstance forces high water usage on a global scale, and arid countries will overburden their water availability and transpire water scarcity. Water scarcity is defined as the demand for freshwater that exceeds its availability [117]. The potential of the RC hydrogel to be used as the plantation medium comes to light subjugated on its properties of porosity and retain water as well as swelling ability that gives rise to the better oxygenation for plants' root due to porosity surge. Due to its excellent water retention ability, the hydrogel is also utilized to absorb and reserve the rainwater or irrigation water, which eventually helps in conserving water [118]. Cellulose is comprised of crystalline (highly ordered regions) and amorphous (less ordered regions) domains intertwined with the matrix of lignin and hemicelluloses subjected to its sources in dictating their compositions. The accessibility of reagents towards cellulose is limited because of its biphasic properties and favorably attacked the amorphous regions. However, various cellulose solutions are being explored [119]. The regeneration process of cellulose I produce cellulose II or amorphous cellulose has provided a better setting for reagents' penetration to the cellulosic fibers whereby, for agriculture purposes, refers to water [120,121]. Water molecules can penetrate the cellulosic fibers attributable to the presence of the hydroxyl groups along the chains of the amorphous cellulose, forming hydrogen bonds [122]. The anisotropic van der Waals forces that exist in the cellulose chains also enhance the forces for strong adsorption energy to hold the water molecules as well as electrostatic interactions.

The interest in using hydrogel in future agriculture is confined to the soilless plantation; however, as the water conserver integrates it with the soil. Intending to water conservation, hydrogels with superabsorbent properties or known as SAHs, are being pursued [123]. Ample research on the modification to increase the strength of SAHs has been pursued because high hydrophilic chains contribute to high water absorption capacity and porosity as well as reduce soil erosion; however, this modification has loosened the structure of the hydrogel. Besides, the weak-gel construction is relatively unsuitable to support the root structure. As a water conserver, a hydrogel that is fabricated from rice straw as the source of cellulose has shown great water absorbance capacity. Hence, it helps reducing water irrigation values, irrigation frequency and strengthens soil aggregation [118]. Demitri, Scalera, Madaghiele, Sannino, and Maffezzoli (2013) showed the mixture of soil and hydrogel with a higher concentration of cellulose-chemically-crosslinked-hydrogel powder exhibits a triplicate water retention capacity tested on the cherry tomato cultivation [124]. Anionic carboxylated-cellulose hydrogel shows higher carboxyl groups in the system with suitable carboxylate content has shown excellent homogenous macroporous structure that enables the hydrogel to retain a good water capacity, subsequently promoting all seedlings growth [125]. Cellulose is also blended with other natural polysaccharides forming a composite that provides strength to the hydrogel while preserving the microporosity and water absorption [113]. The strength provided by the cellulose is suitable for the hydrogel as the plantation medium in conserving water for future soilless farming. Biodegradable synthetic polymers are also employed to be blended, such as grafted poly(acrylic) acid with cellulose to form SAHs that show high swelling capacity due to large pore volume observed due to electrostatic repulsion [115].

\subsection{Long-Shelf Life Plantation Media}

When cellulose is regenerated by the dissolution-regeneration process, a lower degree of crystallinity is obtained, reflecting the high amorphous regions as well as a significant increase in porosity [39]. Crystalline cellulose holds strong interchain hydrogen bonding between adjacent cellulose chains alongside weaker hydrophobic interaction that enacts insolubility and less accessibility [126]. During the dissolution process, the crystalline region of cellulose is disrupted leads to an opportunity for the microbes to cellulose degradation due to its high accessibility property for specific bacterial-enzyme in degrading the polysaccharides chains. Cellulase is known as the specific enzyme functioning to break 
down the cellulose that converts the cellobiose to glucose molecules [127]. There are two types of cellulases known as endocellulase, and exocellulase or cellobiohydrolases, where the former cleaves the internal bond, and the latter degrades the reducing and non-reducing ends of cellulose chains [128]. For instance, RC hydrogel used as the crop plantation medium must have a long degradation time to sustain the plantation for up to four months. Cellulose itself lacks antimicrobial property; ergo, upholding a long degradation time is becoming a challenge. Researchers have invented antimicrobial RC products by impregnating or mixing positively-charged antibacterial agents such as quarternary ammonium compounds into the fabricated products; however, leaching of the antibacterial agents is obtained [129]. Alongside some common non-biodegradable and biodegradable, antibacterial agents have been employed to fabricate antibacterial RC products such as N-halamines, metal oxides, halogenated compounds for the former, and chitosan, alginate, curcumin, allicin for the latter. Cellulose is very flexible due to the abundant hydroxyl groups it possesses for excellent modification, such as antibacterial RC products.

Suitable antibacterial agents must be able to withstand certain temperatures and conditions to be incorporated into RC products, such as during cellulose dissolution (specific temperature applied) or regeneration [130]. As an example, epsilon-poly-L-lysine (EPL), a broad-spectrum antibacterial agents, is used alongside the fabrication of RC beads [131]. Although EPL is stable in both acidic and alkali conditions, it has a leaching problem that can cause contamination; thus, an excellent material such as RC beads is a good candidate to covalently bond with EPL. Alongside, incorporation of EPL into RC beads matrix is shown to have good microorganisms inhibition compared to RC beads alone as well as slower biodegradation rate compared to RC beads. Besides, the high porosity of RC beads has shown the enhancement of antibacterial activity of EPL due to large surface area for grafting oxidation of EPL [132]. Furthermore, the incorporation of chitosan into RC products has shown positive effects on plant growth, antibacterial, antioxidant, and antifungal activities [133]. Chitosan possesses a similar structure to cellulose, where the difference is distinctly observed in the amine group at $C_{2}$. A similar structure drives chitosan and cellulose to have a homogenous blend in forming RC products by using the same cellulose solution system as reported in few studies $[134,135]$. The synergistic between chitosan and endophytic bacteria (soil bacteria) such as Bacillus thuriengensis has shown a reinforcement in fungicidal and insecticidal activity due to the presence of chitin-binding protein inside the particular strain [133].

\subsection{Nutrient Reservoir}

Slow-release fertilizer (SRF) and controlled-release fertilizer (CRF) allow nutrient availability for a longer time by a gradual release of fertilizer compared to the standard fertilizer used in conventional agricultural systems. These improved fertilizing methods reduce nutrient run-off and terminate the need for split application, which incurs cost [136]. The term SRF and CRF are being used interchangeably; however, they portray some differences in fertilizer release mechanisms. Ramli (2019) reported that there are three types of SRF, (1) matrix-type formulations, (2) coating-type, and (3) chemical products [137]. SRF can be formed into granules or tablets, which can be covered by using hydrophobic polymers or matrices and only concerned with the rate of nutrient release at a slower rate while there is no control on the release rate, duration, and patterns driven by environmental conditions such as soil and climate [138]. On the contrary, CRF allows the release of fertilizer based on pattern, duration, and rate of release with several types of formulation listed as (1) organic nitrogen-low-solubility compound, (2) inorganic low-solubility compound, and (3) hydrophobic coating polymer [139]. The similarity of the formulations for both SRF and CRF is the usage of coating polymer to slow/control the release of the fertilizer. Besides, this particular formulation is best represented for agriculture purposes. Coating the fertilizer using polymer will give the immobilization effect, thus, reduce run-off and leaching [140]. The protective coating regulates the water penetration and causes dissolution and nutrient release rate to coincide. Cellulose is best employed as the coating polymer for the SRF, 
and CRF is subjected to its biodegradability, inexpensive, non-toxic as well as possesses hydrophobicity and hydrophilicity [141,142]. The high porosity of RC products has made them suitable for releasing mechanism ability or pictured as transport channel [129].

SRF-hydrogel (SRFH) could be derived from natural or synthetic via matrix or coatingtypes and found to hold water retention and SRF ability. By considering this, RC hydrogel has become the center of attention for researchers in developing SRF for the agriculture industry. Ramli and co-workers used coco peat fiber as the cellulose source to produce RC-SAH via in-situ solution polymerization technique grafted-poly(acrylic acid)/NitrogenPhosphorus-Potassium (NPK) SFRH [143]. The coco peat fiber-SRFH showed a homogenous network, thick and smaller pore sizes that limit the water penetration to reduce the fertilizer release up to five weeks and concur an excellent mechanical property. Zhang and co-researchers prepared hydrogel based on sawdust cellulose-SRF by graft copolymerization and showed a greater water holding capacity due to the introduction of hydroxyl groups and mutually slowed down the fertilizer release in the early and late-stage [144]. The primary methods to produce CRF are using water-insoluble, semipermeable, or impermeable-with-pore polymer coating [139]. The release mechanism is affected by the hydrogel network's gel strength, where lower gel strength leads to an increase in the release rate [144]. There are a few factors that determine excellent SRF/CRF-RC-coated, particle size, gel strength, and porosity. According to Olad and co-workers, the release rate of fertilizer in the SRF was rapidly at the beginning, but as time is increased, the rate of release tended to be low [145]. Wheat straw cellulose hydrogel showed high porosity and small particle to hold water that allows slow release of fertilizer [146]. The high porosity of SRF/CRF-RC-coated reduces the release rate of fertilizer as Aini et al. (2019) showed large pore of rice straw cellulose/urea beads had caused an increase in the urea diffusion rate [147]. Pores promote water diffusion into the network, which results in more water absorption and increases the swelling rate of hydrogel [143]. Therefore, the hydrogels formed should have small porosity and high gel strength to ensure the release rate for fertilizer decreases.

Figure 7 displays an illustration of RC hydrogel hold or coat the urea fertilizer. Li and the co-workers discussed that RC hydrogel is crosslinked hydrophilic polymer networks, which allowed the penetration of water to occur in the capillary action and hydrophilic group dissociated from polymer chain resulted. The phenomenon is called water absorption of the hydrogel. Fertilizer enclosed in the hydrogel will be diffuse and begin to disperse as the difference of concentration gradient between outside and inside hydrogel. Hence, the exchange of water in hydrogel and fertilizer takes place [148]. There are steric effects, and adsorption of fertilizer will be blocked the dissemination of fertilizer. Hence, the nutrients released will be varied and slowed down [146].

The kinetic release from various types of RC hydrogel in the soil has been collected and tabulated in Table 6. Few mathematical models can be used to determine the kinetic release study and the table contain information of correlation coefficient $\left(R^{2}\right)$, which determines the finest fertilizer release study. The release mechanism applies to Fick diffusion when $n$ less than or equal to 0.45 while between 0.45 and 0.89 indicates anomalous transport and when greater than or equal to 0.89 , it shows as release mechanism of Case II $[149,150]$. As when the curve is high goodness of fit $\left(R^{2}>0.96\right)$, the result reveals the model is valid to be employed because the rate of fertilizer release relying on concentration [151]. 

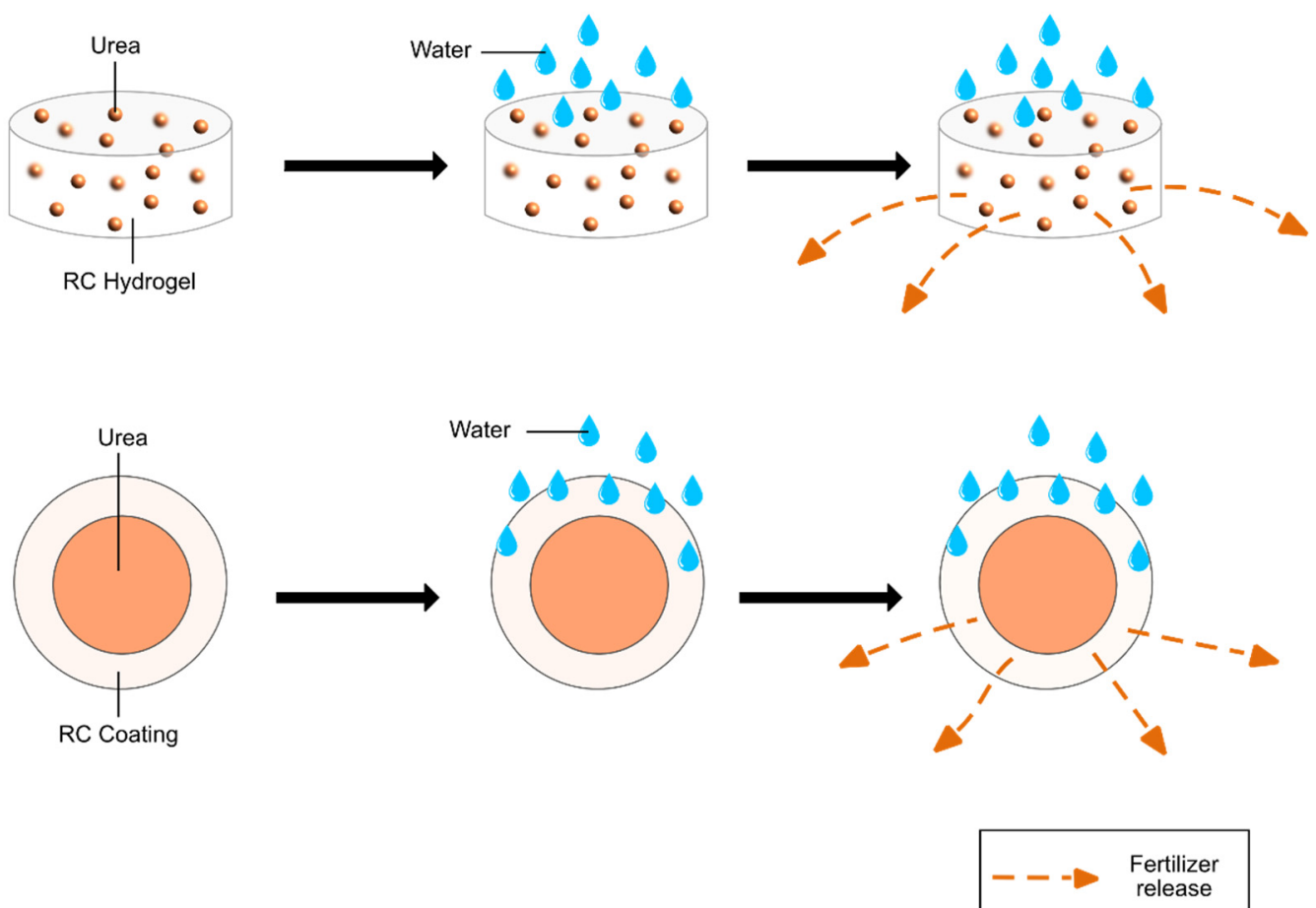

Figure 7. Illustration of RC hold/coat urea fertilizer.

Table 6. Kinetic parameters of different types of RC hydrogels in soil.

\begin{tabular}{|c|c|c|c|c|c|c|c|}
\hline RC Hydrogels & $\begin{array}{l}\text { Source of } \\
\text { Cellulose }\end{array}$ & $\begin{array}{l}\text { Diffusional } \\
\text { Exponent, } n\end{array}$ & $\begin{array}{l}\text { Release Rate } \\
\text { Constant, } k\end{array}$ & $\begin{array}{l}\text { Correlation } \\
\text { Coefficient, } \\
R^{2}\end{array}$ & Model & $\begin{array}{l}\text { Nutrient Release (\%) } \\
\text { Per Time }\end{array}$ & References \\
\hline $\begin{array}{c}\text { Sawdust } \\
\text { cellulose-grafting-poly(acrylic } \\
\text { acid)-poly(acrylamide)-Urea }\end{array}$ & Sawdust & 1.3214 & 0.0012 & 0.9781 & $\begin{array}{l}\text { Ritger- } \\
\text { Peppas }\end{array}$ & $\begin{array}{l}2.4 \% \text { per } 10 \mathrm{~min} \\
8.6 \% \text { per } 30 \mathrm{~min} \\
82.4 \% \text { per } 480 \mathrm{~min}\end{array}$ & [144] \\
\hline Cellulose hydrogel-Urea & $\begin{array}{l}\text { Cellulose } \\
\text { microcrystal }\end{array}$ & 1.4476 & 0.2296 & 0.9899 & $\begin{array}{l}\text { Ritger- } \\
\text { Peppas }\end{array}$ & $\begin{array}{l}22.9 \% \text { per } 1 \text { day } \\
49.5 \% \text { per } 3 \text { days } \\
75.6 \% \text { per } 6 \text { days } \\
91.3 \% \text { per } 10 \text { days } \\
95.71 \% \text { per } 21 \text { days }\end{array}$ & [152] \\
\hline $\begin{array}{c}\text { Salep-g-poly(acrylic } \\
\text { acid)/montmorillonite clay } \\
\text { and NPK }\end{array}$ & Salep & 0.3371 & 0.3004 & 0.9887 & $\begin{array}{l}\text { Korsmeyer- } \\
\text { Peppas }\end{array}$ & $\begin{array}{c}14.12 \% \text { per a day } \\
30.32 \% \text { per a week } \\
55.36 \% \text { per a month }\end{array}$ & [145] \\
\hline $\begin{array}{l}\text { Sulfonated-carboxymethyl } \\
\text { cellulose with acrylic acid in } \\
\text { polyvinylpyrrolidone, silica } \\
\text { nanoparticles and NPK }\end{array}$ & $\begin{array}{l}\text { Carboxymethyl } \\
\text { cellulose }\end{array}$ & 0.3570 & 0.3423 & 0.9862 & $\begin{array}{l}\text { Korsmeyer- } \\
\text { Peppas }\end{array}$ & $\begin{array}{c}14.6 \% \text { per a day } \\
27.6 \% \text { per a week } \\
54.6 \% \text { per a month }\end{array}$ & [153] \\
\hline
\end{tabular}

There are some drawbacks and limitations to using RC as a nutrient reservoir. RC products only cannot retain water properly and do not effective as nutrient reservoirs. Synthetic polymers like polyvinyl alcohol (PVA) have exceptional characteristics such as excellent hydrophilicity, biodegradable, and non-toxicity [154]. Despite that, PVA cannot form the outstanding hydrogel in the aspect of strength and low swelling ratio for use as fertilizer release [155]. Hence, the incorporation of other polymers with cellulose as RC hydrogel for nutrients' reservoir is favorable as to build up the advanced properties of fertilizer release mechanism.

\subsection{Protective Materials}

Mulching can be defined as the spreading of organic or inorganic materials on the soil surface that form a physical barrier that protects crops from soil contamination and maintains the soil's structure [156]. Mulching materials can be divided into organic materials that are derived from animal and plant-based such as coconut husk, rice straw, and cow 
dung, whereas inorganic materials are synthetic materials derived from petroleum-based products such as polyethylene plastic films [157-159]. Plastic mulching has been reported in several preliminary studies to improve the water irrigation performance in agricultural lands that faces drought and is extensively used in agriculture due to its outstanding abilities, such as high hygroscopicity, which improves the soil moisture, temperature as well as enhancing the yield of crops [160-164]. Chopra and Koul (2020) discussed the advantages and disadvantages of using mulches in their work. Although organic mulches are biodegradable and environmentally friendly, they decompose easily and require frequent replenishment in a short period [165].

Apart from mulching films, fruit protection nets also gained a broad research interest in agriculture due to their ability to reduce the amount of radiation received by the crops and also their capability to withstand abiotic and biotic factors that affect the quality and productivity of the crop [166]. The nets diffuse the solar radiation; hence, the crops are exposed to uniform light from all sides and further improve the production and the ripening process of fruits. Furthermore, agricultural nets can moderate the microclimate beneath the nets, which improves the quality of the crop [167]. The application of plastic film has been implemented since the middle of the twentieth century, and fruit nets were mainly utilized as a protection for fruits, to prevent the consumption of pesticide and herbicide, and to protect the crops from wind, rain, and hail [168]. The types of nets can be differentiated through their structural features such as the material of the thread, shape, and dimension of fibers and meshing; and physical properties such as the color of the net, durability, porosity; and mechanical characteristics such as tensile stress, strength, and elongation [169].

The quest to find a suitable degradable material for mulching films has been widely discussed in the research field [170-172]. RC has been prominently studied for its unique properties, such as biodegradability and remarkable mechanical and thermal properties $[173,174]$. Certain essential properties have to be taken into consideration for the application of RC as a mulching film, such as its mechanical properties and tensile strength to avoid fracture in its structure $[175,176]$. Apart from that, the membrane's thermal stability is also important to ensure the prolonged thermal degradation caused by molecular deterioration. Although RC is a biodegradable material, the longevity of this material has to be maximized to reduce frequent replenishments of the mulching films to avoid additional costs.

Crop productivity in the agricultural sector that utilizes plastic mulching is highly dependent on the physical appearance of the mulching material. The effects of different colors of plastic mulches on the development and yield of tomatoes were compared in a study by Mendonça et al. (2021). They reported that dark-colored plastic mulches had an increase in soil temperature [177]. They attributed this to the ability of the mulch to absorb, and more shortwave radiation transmission and similar responses were recorded by Sarkar et al. (2019) [178]. Cellulose-based black mulch film (BMF) was fabricated, and its effect on the soil temperature and yield was studied. It was reported that the BMF depicted the least variance in the soil temperature, which was attributed to the smaller light transmittance and solar radiation $[176,179]$. They further elaborated that a suitable temperature is essential to enhance the growth of plants. The soil temperature is one of the most prominent factors in determining crops' productivity and quality. The usage of colored degradable mulching film aids in creating a distributed soil temperature that promotes the growth of plants. Sintim et al. (2020) co-related the mulch degradation with thermal time in which they reported that the degradability of cellulose occurs only below $55{ }^{\circ} \mathrm{C}$ [180]. The degradation rate for cellulose was reportedly low during higher temperatures. This characteristic of cellulose can be further applied for plastic mulching in areas with higher temperatures to prolong the degradability rate. Owing to the properties above, the ecosystem of the soil can be preserved by reducing synthetic plastic mulching material, which causes negative effects to the soil, such as reducing the soil porosity and inducing plastic waste into the food chains [181-183]. 


\subsection{Biosensors}

Chemical- and bio-sensors have been employed in wide applications that convert the signal into interpretable information for products' quality improvement, and environmental management is an electronic recognition system [184]. A Recognition system is often employed in many fields consisting of the agriculture sector, and immense improvement is being committedly performed for future smart farming. By considering this, sensors are continuously developed to monitor agriculture performance by analyzing few parameters such as soil humidity, heavy metal ions (HMIs) contamination, soil health and diseases, and fertilizer leaching. Cellulose is converted into RC products such as films and fibers because of its biodegradability, non-toxic as well as possessing great hydrophilicity properties. Cellulose-based $\mathrm{pH}$ indicator for ammonia detection is fabricated by mixing cellulose with activated dyes in solution and wash with distilled water as an alternative to the chemical sensors made from metal oxide semiconductor [185]. RC xerogel is developed as an ammonia detection sensor, has shown to exhibit low detection time and high sensitivity that makes cellulose-based sensor is a promising detection system due to the large surfacearea-to-volume ratio and high micro-porosity properties subjected to the dense cellulose fiber network [70]. Chemical sensors that are developed from certain immobilization components commonly leach amid functioning into the detection environment, and this practice is unhealthy, especially in the agriculture sector, thus, by using RC products to covalently immobilize dyes as well as sustainable and biodegradable [185]. The ability of cellulose to immobilize dyes also exhibits a uniform dyes' distribution on the RC film for high detection of heavy metal ions that are present in the irrigation water source [174]. Other than being an immobilization particle for the dyes employed in chemical sensors, cellulose is often being reinforced by other biodegradable synthetic polymers such as polyvinyl alcohol (PVA) to form flexible sensor film because of massive amorphous region of cellulose have aided in enhancing mechanical strength and optical transparency [186]. The humidity level of soil or moisture of the soil is a pivotal parameter to be monitored to yield quality crops. Volumetric water content and root zone leeching checking are usually probed to govern the optimal irrigation frequency influenced by the temperature, soil salinity, and different soil types [187]. The abundant hydroxyl groups in the RC structure make it a natural polymer with a high affinity towards water alongside its transparency and high porosity characteristic that shows that RC products are an excellent candidate for a humidity sensor [188].

\section{Conclusions}

Cellulose is one the most bountiful biomaterial found on Earth that is mostly extracted from the cell wall of plants, and tunicates are widely used in a variety of applications due to their unique characteristics such as good biodegradability that makes it environmentally friendly and green, great mechanical, good thermal strength and non-toxicity. Nonetheless, the application of cellulose is bounded due to its insolubility in water, and it is often counter-measured with the surface modification of the large surface area of cellulose. The dissolution-regeneration process has given cellulose a huge advantage for extensive modification subjected to the changes in the cellulose degree of crystallinity. The more amorphous or less ordered region in RC allows a variety of surface modifications to be carried out as compared to native cellulose. The abundance of $\mathrm{OH}$ groups in cellulose enables it to be tailored according to the applications such as in the medical field, paper industry, packaging, and food industry. However, the application of cellulose in agriculture is yet to be explored extensively.

This review has attempted to give a clear insight into different RC products and their utilization to improve the current conventional agricultural system. The application, as well as research and development of RC in agriculture, are limited at present; hence more resources to explore RC can be carried out to create a more sustainable world that encourages smart farming. The RC products discussed in this review have their own limitations and advantages in the perspective of mechanical strength, cellulose shrinkage 
after regeneration, and fast biodegradability. A variety of materials and techniques to construct the RC products for agriculture purposes are discussed, focusing on the homogeneity blending of $\mathrm{RC}$ with other materials. The blending shows a great potential to increase the end properties of RC products. The development of RC products has a great influence from the following element, (1) dissolution and regeneration solvent type, (2) source of native cellulose (3) type of materials that are blended with RC. A wide range of biodegradable synthetic and natural materials are shown to have good compatibilities with RC as well as exerting excellent properties on the end results. For the future prospect, critical studies on the effect of blending the additional materials before dissolution, during dissolution, during regeneration, or after regeneration on end properties of RC products could be conducted to understand the RC homogeneity in-depth to tailor with the desired applications.

Author Contributions: Conceptualization, N.A.Z.A., A.Z., K.M.S. and S.Z.; Writing-Original Draft Preparation, N.A.Z.A., A.Z., S.G. and S.D.P.; Writing-Review and Editing, N.A.Z.A., Supervision, K.M.S., S.Z. and M.H.C.O., Funding Acquisition, S.Z. All authors have read and agreed to the published version of the manuscript.

Funding: This research was funded by the Malaysian Ministry of Higher Education for LRGS /1/2019/UKM-UKM/5/1 and Universiti Kebangsaan Malaysia, DIP-2018-033.

Institutional Review Board Statement: Not applicable.

Informed Consent Statement: Not applicable.

Acknowledgments: The authors are grateful for the financial support provided by the Malaysian Ministry of Higher Education (MOHE) and Universiti Kebangsaan Malaysia (UKM).

Conflicts of Interest: The authors declared no conflict of interest.

\section{References}

1. Shennan, C.; Krupnik, T.J.; Baird, G.; Cohen, H.; Forbush, K.; Lovell, R.; Olimpi, E.M. Organic and Conventional Agriculture: A Useful Framing? Annu. Rev. Environ. Res. 2017, 42, 317-346. [CrossRef]

2. Kılıç, O.; Boz, I.; Eryılmaz, G.A. Comparison of conventional and good agricultural practices farms: A socio-economic and technical perspective. J. Clean. Prod. 2020, 258, 120666. [CrossRef]

3. Tal, A. Making Conventional Agriculture Environmentally Friendly: Moving beyond the Glorification of Organic Agriculture and the Demonization of Conventional Agriculture. Sustainability 2018, 10, 1078. [CrossRef]

4. Cueff, S.; Alletto, L.; Bourdat-Deschamps, M.; Benoit, P.; Pot, V. Water and pesticide transfers in undisturbed soil columns sampled from a Stagnic Luvisol and a Vermic Umbrisol both cultivated under conventional and conservation agriculture. Geoderma 2020, 377, 114590. [CrossRef]

5. Alcamo, J. Water quality and its interlinkages with the Sustainable Development Goals. Curr. Opin. Environ. Sustain. 2019, 36, 126-140. [CrossRef]

6. Wojtkowski, P. Agroecology; Springer: Cham, Switzerland, 2019; pp. 173-189. [CrossRef]

7. Kumar, M. Agricultural-Based Interventions for Sustainable Food Security \& Climate Change; AkiNik Publications: New Delhi, India, 2018.

8. Maji, B. Introduction to Natural Polysaccharides; Elsevier Ltd.: Philadelphia, PA, USA, 2019; pp. 1-31.

9. Rozo, G.; Bohorques, L.; Santamaría, J. Controlled release fertilizer encapsulated by a K-carrageenan hydrogel. Polimeros 2019, 29, 1-12. [CrossRef]

10. Kaco, H.; Zakaria, S.; Chia, C.H.; Zhang, L. Transparent and Printable Regenerated Kenaf Cellulose/PVA Film. Bioresources 2014, 9, 2167-2178. [CrossRef]

11. Salleh, K.M.; Zakaria, S.; Sajab, M.S.; Gan, S.; Chia, C.H.; Jaafar, S.N.S.; Amran, U.A. Chemically crosslinked hydrogel and its driving force towards superabsorbent behaviour. Int. J. Biol. Macromol. 2018, 118, 1422-1430. [CrossRef]

12. Singh, P.; Duarte, H.; Alves, L.; Antunes, F.; Le Moigne, N.; Dormanns, J.; Duchemin, B.; Staiger, M.P.; Medronho, B. From Cellulose Dissolution and Regeneration to Added Value Applications-Synergism Between Molecular Understanding and Material Development. In Cellulose-Fundamental Aspects and Current Trends; IntechOpen: London, UK, 2015; pp. 1-44. [CrossRef]

13. Orzali, L.; Corsi, B.; Forni, C.; Riccioni, L. Chitosan in Agriculture: A New Challenge for Managing Plant Disease. In Biological Activities and Application of Marine Polysaccharides; InTech: London, UK, 2017.

14. Llanes, L.; Dubessay, P.; Pierre, G.; Delattre, C.; Michaud, P. Biosourced Polysaccharide-Based Superabsorbents. Polysaccharides 2020, 1, 5. [CrossRef] 
15. Amran, U.A.; Zakaria, S.; Chia, C.H.; Roslan, R.; Jaafar, S.N.S.; Salleh, K.M. Polyols and rigid polyurethane foams derived from liquefied lignocellulosic and cellulosic biomass. Cellulose 2019, 26, 3231-3246. [CrossRef]

16. Gan, S.; Zakaria, S.; Chia, C.H.; Kaco, H. Effect of graphene oxide on thermal stability of aerogel bio-nanocomposite from cellulose-based waste biomass. Cellulose 2018, 25, 5099-5112. [CrossRef]

17. Wustenberg, T. Cellulose and Cellulose Derivatives in the Food Industry, 2nd ed.; Wiley-VCH: Weinheim, Germany, 2012.

18. Gupta, V.K.; Carrott, P.J.M.; Singh, R.; Chaudhary, M.; Kushwaha, S. Cellulose: A review as natural, modified and activated carbon adsorbent. Bioresour. Technol. 2016, 216, 1066-1076. [CrossRef]

19. Baharin, K.W.; Zakaria, S.; Ellis, A.V.; Talip, N.; Kaco, H.; Gan, S.; Zailan, F.D.; Hashim, S.N.A.S. Factors affecting cellulose dissolution of oil palm empty fruit bunch and kenaf pulp in NaOH/urea solvent. St. Malays. 2018, 47, 377-386. [CrossRef]

20. Poletto, M.; Ornaghi, J.H.L.; Zattera, A.J. Native Cellulose: Structure, Characterization and Thermal Properties. Material 2014, 7 , 6105-6119. [CrossRef] [PubMed]

21. Hidaka, H.; Kim, U.-J.; Wada, M. Synchrotron X-ray fiber diffraction study on the thermal expansion behavior of cellulose crystals in tension wood of Japanese poplar in the low-temperature region. Holzforschung 2010, 64, 167-171. [CrossRef]

22. Qi, H.; Chang, C.; Zhang, L. Effects of temperature and molecular weight on dissolution of cellulose in $\mathrm{NaOH} /$ urea aqueous solution. Cellulose 2008, 15, 779-787. [CrossRef]

23. Park, S.; Baker, J.O.; Himmel, M.E.; Parilla, P.A.; Johnson, D.K. Cellulose crystallinity index: Measurement techniques and their impact on interpreting cellulase performance. Biotechnol. Biofuels 2010, 3, 10. [CrossRef]

24. Gan, S.Y.; Zakaria, S.; Chia, C.H.; Chen, R.S.; Ellis, A.; Kaco, H. Highly porous regenerated cellulose hydrogel and aerogel prepared from hydrothermal synthesized cellulose carbamate. PLoS ONE 2017, 12, e0173743. [CrossRef]

25. Sayyed, A.; Deshmukh, N.A.; Pinjari, D.V. A critical review of manufacturing processes used in regenerated cellulosic fibres: Viscose, cellulose acetate, cuprammonium, LiCl/DMAc, ionic liquids, and NMMO based lyocell. Cellulose 2019, 26, 2913-2940. [CrossRef]

26. Berga, L.; Bruce, I.; Nicol, T.W.J.; Holding, A.J.; Isobe, N.; Shimizu, S.; Walker, A.J.; Reid, J.E.S.J. Cellulose dissolution and regeneration using a non-aqueous, non-stoichiometric protic ionic liquid system. Cellulose 2020, 27, 9593-9603. [CrossRef]

27. Egal, M.; Budtova, T.; Navard, P. Structure of Aqueous Solutions of Microcrystalline Cellulose/Sodium Hydroxide below $0{ }^{\circ} \mathrm{C}$ and the Limit of Cellulose Dissolution. Biomacromolecules 2007, 8, 2282-2287. [CrossRef] [PubMed]

28. Zhang, S.; Chen, C.; Duan, C.; Hu, H.; Li, H.; Li, J.; Liu, Y.; Ma, X.; Stavik, J.; Ni, Y. Regenerated cellulose by the Lyocell process, a brief review of the process and properties. Bioresources 2018, 13, 4577-4592. [CrossRef]

29. Kasprzak, D.; Krystkowiak, E.; Stępniak, I.; Galiński, M. Dissolution of cellulose in novel carboxylate-based ionic liquids and dimethyl sulfoxide mixed solvents. Eur. Polym. J. 2019, 113, 89-97. [CrossRef]

30. Ma, Y.; Rissanen, M.; You, X.; Moriam, K.; Hummel, M.; Sixta, H. New method for determining the degree of fibrillation of regenerated cellulose fibres. Cellulose 2021, 28, 31-44. [CrossRef]

31. Isobe, N.; Kimura, S.; Wada, M.; Kuga, S. Mechanism of cellulose gelation from aqueous alkali-urea solution. Carbohydr. Polym. 2012, 89, 1298-1300. [CrossRef]

32. Liu, W.; Liu, S.; Liu, T.; Liu, T.; Zhang, J.; Liu, H. Eco-friendly post-consumer cotton waste recycling for regenerated cellulose fibers. Carbohydr. Polym. 2019, 206, 141-148. [CrossRef] [PubMed]

33. Sun, L.; Chen, J.Y.; Jiang, W.; Lynch, V. Crystalline characteristics of cellulose fiber and film regenerated from ionic liquid solution. Carbohydr. Polym. 2015, 118, 150-155. [CrossRef]

34. Elsayed, S.; Hellsten, S.; Guizani, C.; Witos, J.; Rissanen, M.; Rantamäki, A.H.; Varis, P.; Wiedmer, S.; Sixta, H. Recycling of Superbase-Based Ionic Liquid Solvents for the Production of Textile-Grade Regenerated Cellulose Fibers in the Lyocell Process. ACS Sustain. Chem. Eng. 2020, 8, 14217-14227. [CrossRef]

35. Pang, J.; Wu, M.; Zhang, Q.; Tan, X.; Xu, F.; Zhang, X.; Sun, R. Comparison of physical properties of regenerated cellulose films fabricated with different cellulose feedstocks in ionic liquid. Carbohydr. Polym. 2015, 121, 71-78. [CrossRef]

36. Liu, Z.; Sun, X.; Hao, M.; Huang, C.; Xue, Z.; Mu, T. Preparation and characterization of regenerated cellulose from ionic liquid using different methods. Carbohydr. Polym. 2015, 117, 99-105. [CrossRef]

37. Egal, M.; Budtova, T.; Navard, P. The dissolution of microcrystalline cellulose in sodium hydroxide-urea aqueous solutions. Cellulose 2007, 15, 361-370. [CrossRef]

38. Tu, H.; Zhu, M.; Duan, B.; Zhang, L. Recent Progress in High-Strength and Robust Regenerated Cellulose Materials. Adv. Mater. 2021, 33, 1-22. [CrossRef] [PubMed]

39. Zhang, K.; Xiao, H.; Su, Y.; Wu, Y.; Cui, Y.; Li, M. Mechanical and physical properties of regenerated biomass composite films from lignocellulosic materials in ionic liquid. Bioresources 2019, 14, 2584-2595. [CrossRef]

40. Santamala, H.; Livingston, R.; Sixta, H.; Hummel, M.; Skrifvars, M.; Saarela, O. Advantages of regenerated cellulose fibres as compared to flax fibres in the processability and mechanical performance of thermoset composites. Compos. Part A Appl. Sci. Manuf. 2016, 84, 377-385. [CrossRef]

41. Zhou, Q.; Bao, Y.; Zhang, H.; Luan, Q.; Tang, H.; Li, X. Regenerated cellulose-based composite membranes as adsorbent for protein adsorption. Cellulose 2019, 27, 335-345. [CrossRef]

42. Huang, Z.; Liu, C.; Feng, X.; Wu, M.; Tang, Y.; Li, B. Effect of regeneration solvent on the characteristics of regenerated cellulose from lithium bromide trihydrate molten salt. Cellulose 2020, 27, 9243-9256. [CrossRef] 
43. Azmi, A.; Lau, K.S.; Chin, S.X.; Khiew, P.S.; Zakaria, S.; Chia, C.H. ZnO filled PVA cellulose nanifibril aerogel nanocomposite for catalytic decomposition of an organic dye in aqueous solution. Cellulose 2021, 28, 2241-2253. [CrossRef]

44. Esfahani, M.R.; Taylor, A.; Serwinowski, N.; Parkerson, Z.; Confer, M.P.; Kammakakam, I.; Bara, J.E.; Esfahani, A.; Mahmoodi, S.N.; Koutahzadeh, N.; et al. Sustainable Novel Bamboo-Based Membranes for Water Treatment Fabricated by Regeneration of Bamboo Waste Fibers. ACS Sustain. Chem. Eng. 2020, 8, 4225-4235. [CrossRef]

45. Adsul, M.; Soni, S.K.; Bhargava, S.K.; Bansal, V. Facile Approach for the Dispersion of Regenerated Cellulose in Aqueous System in the Form of Nanoparticles. Biomacromolecules 2012, 13, 2890-2895. [CrossRef]

46. Song, B.; Liang, H.; Sun, R.; Peng, P.; Jiang, Y.; She, D. Hydrogel synthesis based on lignin/sodium alginate and application in agriculture. Int. J. Biol. Macromol. 2020, 144, 219-230. [CrossRef]

47. Xing, L.; Hu, C.; Zhang, W.; Guan, L.; Gu, J. Transition of cellulose supramolecular structure during concentrated acid treatment and its implication for cellulose nanocrystal yield. Carbohydr. Polym. 2020, 229, 115539. [CrossRef]

48. Tyshkunova, I.V.; Chukhchin, D.G.; Gofman, I.V.; Poshina, D.N.; Skorik, Y.A. Cellulose cryogels prepared by regeneration from phosphoric acid solutions. Cellulose 2021, 28, 1-15. [CrossRef]

49. Li, N.; Bian, H.; Zhu, J.; Ciesielski, P.N.; Pan, X. Tailorable cellulose II nanocrystals (CNC II) prepared in mildly acidic lithium bromide trihydrate (MALBTH). Green Chem. 2021, 23, 2778-2791. [CrossRef]

50. Pakutsah, K.; Aht-Ong, D. Eco-Friendly Preparation of Nanofibrillated Cellulose from Water Hyacinth Using NaOH/Urea Pretreatment. Mater. Sci. Forum 2020, 990, 225-230. [CrossRef]

51. Bian, H.; Tu, P.; Chen, J.Y. Fabrication of all-cellulose nanocomposites from corn stalk. J. Sci. Food Agric. 2020, 100, 4390-4399. [CrossRef] [PubMed]

52. Kabir, S.M.F.; Sikdar, P.P.; Haque, B.; Bhuiyan, M.A.R.; Ali, A.; Islam, M.N. Cellulose-based hydrogel materials: Chemistry, properties and their prospective applications. Prog. Biomater. 2018, 7, 153-174. [CrossRef]

53. Maharjan, B.; Park, J.; Kaliannagounder, V.K.; Awasthi, G.P.; Joshi, M.K.; Park, C.H.; Kim, C.S. Regenerated cellulose nanofiber reinforced chitosan hydrogel scaffolds for bone tissue engineering. Carbohydr. Polym. 2021, 251, 117023. [CrossRef]

54. Sasmal, P.K.; Patra, S. Effect in Growth of Corn Plant from Cellulose-Based Hydrogel Derived from Wheat Straw. J. Inst. Eng. Ser. E 2020, 1-6. [CrossRef]

55. Hu, W.; Wang, Z.; Xiao, Y.; Zhang, S.; Wang, J. Advances in crosslinking strategies of biomedical hydrogels. Biomater. Sci. 2019, 7, 843-855. [CrossRef]

56. Ranganathan, N.; Bensingh, R.J.; Kader, M.A.; Nayak, S.K. Synthesis and Properties of Hydrogels Prepared by Various Polymerization Reaction Systems; Springer International Publishing: Cham, Switzerland, 2019; pp. 487-511.

57. Zhang, Q.; Wu, M.; Hu, X.; Lu, W.; Wang, M.; Li, T.; Zhao, Y. A Novel Double-Network, Self-Healing Hydrogel Based on Hydrogen Bonding and Hydrophobic Effect. Macromol. Chem. Phys. 2019, 221, 1900320. [CrossRef]

58. Treesuppharat, W.; Rojanapanthu, P.; Siangsanoh, C.; Manuspiya, H.; Ummartyotin, S. Synthesis and characterization of bacterial cellulose and gelatin-based hydrogel composites for drug-delivery systems. Biotechnol. Rep. 2017, 15, 84-91. [CrossRef] [PubMed]

59. De France, K.; D’Emilio, E.; Cranston, E.D.; Geiger, T.; Nyström, G. Dual physically and chemically crosslinked regenerated cellulose-Gelatin composite hydrogels towards art restoration. Carbohydr. Polym. 2020, 234, 115885. [CrossRef] [PubMed]

60. Teng, J.; Yang, B.; Zhang, L.-Q.; Lin, S.-Q.; Xu, L.; Zhong, G.-J.; Tang, J.-H.; Li, Z.-M. Ultra-high mechanical properties of porous composites based on regenerated cellulose and cross-linked poly(ethylene glycol). Carbohydr. Polym. 2018, 179, 244-251. [CrossRef]

61. Yang, B.; Hua, W.; Li, L.; Zhou, Z.; Xu, L.; Bian, F.; Ji, X.; Zhong, G.; Li, Z. Robust hydrogel of regenerated cellulose by chemical crosslinking coupled with polyacrylamide network. J. Appl. Polym. Sci. 2019, 136, 1-10. [CrossRef]

62. Xia, Z.; Li, J.; Zhang, J.; Zhang, X.; Zheng, X.; Zhang, J. Processing and valorization of cellulose, lignin and lignocellulose using ionic liquids. J. Bioresour. Bioprod. 2020, 5, 79-95. [CrossRef]

63. Seiler, E.; Koyama, K.; Iijima, T.; Saito, T.; Takeoka, Y.; Rikukawa, M.; Yoshizawa-Fujita, M. Simple and Fast One-Pot Cellulose Gel Preparation in Aqueous Pyrrolidinium Hydroxide Solution-Cellulose Solvent and Antibacterial Agent. Polymers 2021, $13,1942$. [CrossRef]

64. Karadagli, I.; Schulz, B.; Schestakow, M.; Milow, B.; Gries, T.; Ratke, L. Production of porous cellulose aerogel fibers by an extrusion process. J. Supercrit. Fluids 2015, 106, 105-114. [CrossRef]

65. Tang, Y.; Wang, H.; Hou, D.; Tan, H.; Yang, M. Regenerated cellulose aerogel: Morphology control and the application as the template for functional cellulose nanoparticles. J. Appl. Polym. Sci. 2020, 137, 1-11. [CrossRef]

66. Liu, S.; Tao, D.; Zhang, L. Cellulose scaffold: A green template for the controlling synthesis of magnetic inorganic nanoparticles. Powder Technol. 2012, 217, 502-509. [CrossRef]

67. Ciolacu, D.; Rudaz, C.; Vasilescu, M.; Budtova, T. Physically and chemically cross-linked cellulose cryogels: Structure, properties and application for controlled release. Carbohydr. Polym. 2016, 151, 392-400. [CrossRef]

68. Yamasaki, S.; Sakuma, W.; Yasui, H.; Daicho, K.; Saito, T.; Fujisawa, S.; Isogai, A.; Kanamori, K. Nanocellulose Xerogels with High Porosities and Large Specific Surface Areas. Front. Chem. 2019, 7, 316. [CrossRef] [PubMed]

69. Long, L.-Y.; Weng, Y.-X.; Wang, Y.-Z. Cellulose Aerogels: Synthesis, Applications, and Prospects. Polymers 2018, 10, 623. [CrossRef] [PubMed]

70. Khattab, T.A.; Dacrory, S.; Abou-Yousef, H.; Kamel, S. Development of microporous cellulose-based smart xerogel reversible sensor via freeze drying for naked-eye detection of ammonia gas. Carbohydr. Polym. 2019, 210, 196-203. [CrossRef] 
71. Elanchezhian, C.; Ramnath, B.; Ramakrishnan, G.; Rajendrakumar, M.; Naveenkumar, V.; Saravanakumar, M. Review on mechanical properties of natural fiber composites. Mater. Today Proc. 2018, 5, 1785-1790. [CrossRef]

72. Anuar, N.I.S.; Zakaria, S.; Gan, S.; Chia, C.H.; Wang, C.; Harun, J. Comparison of the morphological and mechanical properties of oil Palm EFB fibres and kenaf fibres in nonwoven reinforced composites. Ind. Crop. Prod. 2019, 127, 55-65. [CrossRef]

73. Nguyen, H.; Zatar, W.; Mutsuyoshi, H. Mechanical Properties of Hybrid Polymer Composite; Elsevier Ltd.: Philadelphia, PA, USA, 2017; pp. 83-113.

74. Ramamoorthy, S.K.; Skrifvars, M.; Persson, A. A Review of Natural Fibers Used in Biocomposites: Plant, Animal and Regenerated Cellulose Fibers. Polym. Rev. 2015, 55, 107-162. [CrossRef]

75. Yu, M.-C.; Wan, J.-X. Environmental Friendly Development of Regenerated Cellulose Fiber Production. DEStech Trans. Eng. Technol. Res. 2017, 760-765. [CrossRef]

76. Wang, X.; Yan, Q.; Gao, X.; Wang, S.; He, Y.; Zhang, L. Infrared and fluorescence properties of reduced graphene oxide/regenerated cellulose composite fibers. BioResources 2020, 15, 4434-4448. [CrossRef]

77. Nadhan, A.V.; Rajulu, A.V.; Li, R.; Jie, C.; Zhang, L. Properties of Regenerated Cellulose Short Fibers/Cellulose Green Composite Films. J. Polym. Environ. 2011, 20, 454-458. [CrossRef]

78. Tian, M.; Qu, L.; Zhang, X.; Zhang, K.; Zhu, S.; Guo, X.; Han, G.; Tang, X.; Sun, Y. Enhanced mechanical and thermal properties of regenerated cellulose/graphene composite fibers. Carbohydr. Polym. 2014, 111, 456-462. [CrossRef]

79. Ramamoorthy, S.K.; Kundu, C.K.; Adekunle, K.; Bashir, T.; Skrifvars, M.O.V. Properties of green composites with regenerated cellulose fiber and soybean-based thermoset for technical applications. J. Reinf. Plast. Compos. 2013, 33, 193-201. [CrossRef]

80. Klar, V.; Orelma, H.; Rautkoski, H.; Kuosmanen, P.; Harlin, A. Spinning Approach for Cellulose Fiber Yarn Using a Deep Eutectic Solvent and an Inclined Channel. ACS Omega 2018, 3, 10918-10926. [CrossRef] [PubMed]

81. De Silva, R.; Vongsanga, K.; Wang, X.; Byrne, N. Cellulose regeneration in ionic liquids: Factors controlling the degree of polymerisation. Cellulose 2015, 22, 2845-2849. [CrossRef]

82. Orelma, H.; Hokkanen, A.; Leppänen, I.; Kammiovirta, K.; Kapulainen, M.; Harlin, A. Optical cellulose fiber made from regenerated cellulose and cellulose acetate for water sensor applications. Cellulose 2020, 27, 1543-1553. [CrossRef]

83. Yang, Y.; Zhang, Y.; Dawelbeit, A.; Deng, Y.; Lang, Y.; Yu, M. Structure and properties of regenerated cellulose fibers from aqueous $\mathrm{NaOH} /$ thiourea/urea solution. Cellulose 2017, 24, 4123-4137. [CrossRef]

84. Qiu, C.; Zhu, K.; Zhou, X.; Luo, L.; Zeng, J.; Huang, R.; Lu, A.; Liu, X.; Chen, F.; Zhang, L.; et al. Influences of Coagulation Conditions on the Structure and Properties of Regenerated Cellulose Filaments via Wet-Spinning in LiOH/Urea Solvent. ACS Sustain. Chem. Eng. 2018, 6, 4056-4067. [CrossRef]

85. Jiang, G.; Yuan, Y.; Wang, B.; Yin, X.; Mukuze, K.S.; Huang, W.; Zhang, Y.; Wang, H. Analysis of regenerated cellulose fibers with ionic liquids as a solvent as spinning speed is increased. Cellulose 2012, 19, 1075-1083. [CrossRef]

86. Lu, F.; Cheng, B.; Song, J.; Liang, Y. Rheological characterization of concentrated cellulose solutions in 1-allyl-3-methylimidazolium chloride. J. Appl. Polym. Sci. 2012, 124, 3419-3425. [CrossRef]

87. Sun, H.; Miao, J.; Yu, Y.; Zhang, L. Dissolution of cellulose with a novel solvent and formation of regenerated cellulose fiber. Appl. Phys. A 2015, 119, 539-546. [CrossRef]

88. Ma, Y.; Nasri-Nasrabadi, B.; You, X.; Wang, X.; Rainey, T.J.; Byrne, N. Regenerated Cellulose Fibers Wetspun from Different Waste Cellulose Types. J. Nat. Fibers 2020, 17, 1-13. [CrossRef]

89. Uddin, A.J.; Yamamoto, A.; Gotoh, Y.; Nagura, M.; Iwata, M. Preparation and Physical Properties of Regenerated Cellulose Fibres from Sugarcane Bagasse. Text. Res. J. 2010, 80, 1846-1858. [CrossRef]

90. Zhang, J.; Tominaga, K.; Yamagishi, N.; Gotoh, Y. Comparison of Regenerated Cellulose Fibers Spun from Ionic Liquid Solutions with Lyocell Fiber. J. Fiber Sci. Technol. 2020, 76, 257-266. [CrossRef]

91. Mohamed, M.A.; Salleh, W.W.; Jaafar, J.; Hir, Z.A.M.; Rosmi, M.S.; Mutalib, M.A.; Ismail, A.F.; Tanemura, M. Regenerated cellulose membrane as bio-template for in-situ growth of visible-light driven C-modified mesoporous titania. Carbohydr. Polym. 2016, 146, 166-173. [CrossRef]

92. Xiong, X.; Duan, J.; Zou, W.; He, X.; Zheng, W. A pH-sensitive regenerated cellulose membrane. J. Membr. Sci. 2010, 363, 96-102. [CrossRef]

93. Wang, S.; Lu, A.; Zhang, L. Recent advances in regenerated cellulose materials. Prog. Polym. Sci. 2016, 53, 169-206. [CrossRef]

94. Czesław, Ś; Beata, F. Structure-Property Relationships of Pure Cellulose and GO/CEL Membranes Regenerated from Ionic. Polymers 2019, 11, 1178.

95. Mohamed, M.A.; Salleh, W.; Jaafar, J.; Ismail, A.F.; Mutalib, M.A.; Jamil, S.M. Incorporation of N-doped TiO ${ }_{2}$ nanorods in regenerated cellulose thin films fabricated from recycled newspaper as a green portable photocatalyst. Carbohydr. Polym. 2015, 133, 429-437. [CrossRef]

96. Zheng, X.; Huang, F.; Chen, L.; Huang, L.; Cao, S.; Ma, X. Preparation of transparent film via cellulose regeneration: Correlations between ionic liquid and film properties. Carbohydr. Polym. 2019, 203, 214-218. [CrossRef] [PubMed]

97. Li, X.; Li, H.-C.; You, T.-T.; Wu, Y.-Y.; Ramaswamy, S.; Xu, F. Fabrication of regenerated cellulose membranes with high tensile strength and antibacterial property via surface amination. Ind. Crop. Prod. 2019, 140, 111603. [CrossRef]

98. Le, N.L.; Nunes, S.P. Materials and membrane technologies for water and energy sustainability. Sustain. Mater. Technol. 2016, 7, 1-28. [CrossRef]

99. Boretti, A.; Rosa, L. Reassessing the projections of the World Water Development Report. NPJ Clean Water 2019, 2, 1-6. [CrossRef] 
100. Houngbo, G. Nature-Based Solutions for Water; UNESCO Publishing: Paris, France, 2018.

101. Hu, M.-X.; Niu, H.-M.; Chen, X.-L.; Zhan, H.-B. Natural cellulose microfiltration membranes for oil/water nanoemulsions separation. Colloids Surf. A Physicochem. Eng. Asp. 2019, 564, 142-151. [CrossRef]

102. Ao, C.; Hu, R.; Zhao, J.; Zhang, X.; Li, Q.; Xia, T.; Zhang, W.; Lu, C. Reusable, salt-tolerant and superhydrophilic cellulose hydrogel-coated mesh for efficient gravity-driven oil/water separation. Chem. Eng. J. 2018, 338, 271-277. [CrossRef]

103. Halim, A.; Xu, Y.; Lin, K.-H.; Kobayashi, M.; Kajiyama, M.; Enomae, T. Fabrication of cellulose nanofiber-deposited cellulose sponge as an oil-water separation membrane. Sep. Purif. Technol. 2019, 224, 322-331. [CrossRef]

104. Fan, T.; Qian, Q.; Hou, Z.; Liu, Y.; Lu, M. Preparation of smart and reversible wettability cellulose fabrics for oil/water separation using a facile and economical method. Carbohydr. Polym. 2018, 200, 63-71. [CrossRef] [PubMed]

105. Yagoub, H.; Zhu, L.; Shibraen, M.H.; Altam, A.A.; Babiker, D.M.; Rehan, K.; Mukwaya, V.; Xu, J.; Yang, S. Manipulating the surface wettability of polysaccharide based complex membrane for oil/water separation. Carbohydr. Polym. 2019, $225,115231$. [CrossRef] [PubMed]

106. Ei-Kazzaz, A. Soilless Agriculture a New and Advanced Method for Agriculture Development: An Introduction. Agric. Res. Technol. Open Access J. 2017, 3, 555610. [CrossRef]

107. Majeed, Z.; Ramli, N.K.; Mansor, N.; Man, Z. A comprehensive review on biodegradable polymers and their blends used in controlled-release fertilizer processes. Rev. Chem. Eng. 2015, 31, 69-95. [CrossRef]

108. Sambo, P.; Nicoletto, C.; Giro, A.; Pii, Y.; Valentinuzzi, F.; Mimmo, T.; Lugli, P.; Orzes, G.; Mazzetto, F.; Astolfi, S.; et al. Hydroponic Solutions for Soilless Production Systems: Issues and Opportunities in a Smart Agriculture Perspective. Front. Plant Sci. 2019, 10, 923. [CrossRef] [PubMed]

109. Pradhan, B.; Deo, B. Soilless Farming-The Next Generation Green Revolution. Curr. Sci. 2019, 116, 728-732. [CrossRef]

110. Muller, A.; Ferré, M.; Engel, S.; Gattinger, A.; Holzkämper, A.; Huber, R.; Müller, M.; Six, J. Can soil-less crop production be a sustainable option for soil conservation and future agriculture? Land Use Policy 2017, 69, 102-105. [CrossRef]

111. Ranganathan, N.; Bensingh, R.J.; Kader, M.A.; Nayak, S.K. Cellulose-Based Hydrogels for Agricultures; Springer: Cham, Switzerland, 2019; pp. 1039-1059. [CrossRef]

112. Kassem, I.; Kassab, Z.; Khouloud, M.; Sehaqui, H.; Bouhfid, R.; Jacquemin, J.; Qaiss, A.E.K.; El Achaby, M. Phosphoric acidmediated green preparation of regenerated cellulose spheres and their use for all-cellulose cross-linked superabsorbent hydrogels. Int. J. Biol. Macromol. 2020, 162, 136-149. [CrossRef] [PubMed]

113. Zhang, H.; Luan, Q.; Huang, Q.; Tang, H.; Huang, F.; Li, W.; Wan, C.; Liu, C.; Xu, J.; Guo, P.; et al. A facile and efficient strategy for the fabrication of porous linseed gum/cellulose superabsorbent hydrogels for water conservation. Carbohydr. Polym. 2017, 157, 1830-1836. [CrossRef]

114. Zainal, S.H.; Nofrianti, R.; Lazim, A.M.; Othaman, R. Cellulose-based hydrogel as Halal agricultural medium. Malays. Appl. Biol. 2019, 48, 109-113.

115. Ibrahim, M.M.; Abd-Eladl, M.; Abou-Baker, N. Lignocellulosic biomass for the preparation of cellulose-based hydrogel and its use for optimizing water resources in agriculture. J. Appl. Polym. Sci. 2015, 132, 1-12. [CrossRef]

116. Santoso, S.P.; Kurniawan, A.; Soetaredjo, F.E.; Cheng, K.-C.; Putro, J.; Ismadji, S.; Ju, Y.-H. Eco-friendly cellulose-bentonite porous composite hydrogels for adsorptive removal of azo dye and soilless culture. Cellulose 2019, 26, 3339-3358. [CrossRef]

117. Rosa, L.; Chiarelli, D.D.; Rulli, M.C.; Dell'Angelo, J.; D’Odorico, P. Global agricultural economic water scarcity. Sci. Adv. 2020, 6, eaaz6031. [CrossRef]

118. Abou-Baker, N.; Ouis, M.; Abd-Eladl, M.; Ibrahim, M.M. Transformation of Lignocellulosic Biomass to Cellulose-Based Hydrogel and Agriglass to Improve Beans Yield. Waste Biomass Valorization 2019, 11, 3537-3551. [CrossRef]

119. Ciolacu, D.; Ciolacu, F.; Popa, V.I. Amorphous Cellulose-Structure and Characterization. Cellulose Chem. Technol. 2011, 45, 13-21.

120. Ling, Z.; Chen, S.; Zhang, X.; Takabe, K.; Xu, F. Unraveling variations of crystalline cellulose induced by ionic liquid and their effects on enzymatic hydrolysis. Sci. Rep. 2017, 7, 1-11. [CrossRef]

121. Halonen, H.; Larsson, P.T.; Iversen, T. Mercerized cellulose biocomposites: A study of influence of mercerization on cellulose supramolecular structure, water retention value and tensile properties. Cellulose 2013, 20, 57-65. [CrossRef]

122. Khazraji, A.C.; Robert, S. Interaction Effects between Cellulose and Water in Nanocrystalline and Amorphous Regions: A Novel Approach Using Molecular Modeling. J. Nanomater. 2013, 2013, 1-10. [CrossRef]

123. Chang, C.; Duan, B.; Cai, J.; Zhang, L. Superabsorbent hydrogels based on cellulose for smart swelling and controllable delivery. Eur. Polym. J. 2010, 46, 92-100. [CrossRef]

124. Demitri, C.; Scalera, F.; Madaghiele, M.; Sannino, A.; Maffezzoli, A. Potential of Cellulose-Based Superabsorbent Hydrogels as Water Reservoir in Agriculture. Int. J. Polym. Sci. 2013, 2013, 1-6. [CrossRef]

125. Zhang, H.; Yang, M.; Luan, Q.; Tang, H.; Huang, F.; Xiang, X.; Yang, C.; Bao, Y. Cellulose Anionic Hydrogels Based on Cellulose Nanofibers as Natural Stimulants for Seed Germination and Seedling Growth. J. Agric. Food Chem. 2017, 65, 3785-3791. [CrossRef]

126. Wang, S.; Zhao, D.; Bai, X.; Zhang, W.; Lu, X. Identification and Characterization of a Large Protein Essential for Degradation of the Crystalline Region of Cellulose by Cytophaga hutchinsonii. Appl. Environ. Microbiol. 2017, 83, 1-16. [CrossRef] [PubMed]

127. López-Mondéjar, R.; Zühlke, D.; Becher, D.; Riedel, K.; Baldrian, P. Cellulose and hemicellulose decomposition by forest soil bacteria proceeds by the action of structurally variable enzymatic systems. Sci. Rep. 2016, 6, 25279. [CrossRef]

128. Leppänen, I.; Vikman, M.; Harlin, A.; Orelma, H. Enzymatic Degradation and Pilot-Scale Composting of Cellulose-Based Films with Different Chemical Structures. J. Polym. Environ. 2019, 28, 458-470. [CrossRef] 
129. Pan, Y.; Zhao, X.; Li, X.; Cai, P. Green-Based Antimicrobial Hydrogels Prepared from Bagasse Cellulose as 3D-Scaffolds for Wound Dressing. Polymers 2019, 11, 1846. [CrossRef]

130. Edgar, K.J.; Zhang, H. Antibacterial modification of Lyocell fiber: A review. Carbohydr. Polym. 2020, 250, 116932. [CrossRef]

131. Wu, H.; Hu, S.; Nie, C.; Zhang, J.; Tian, H.; Hu, W.; Shen, T.; Wang, J. Fabrication and characterization of antibacterial epsilonpoly-L-lysine anchored dicarboxyl cellulose beads. Carbohydr. Polym. 2021, 255, 117337. [CrossRef]

132. Nie, C.; Shen, T.; Hu, W.; Ma, Q.; Zhang, J.; Hu, S.; Tian, H.; Wu, H.; Luo, X.; Wang, J. Characterization and antibacterial properties of epsilon-poly- 1-lysine grafted multi-functional cellulose beads. Carbohydr. Polym. 2021, 262, 117902. [CrossRef]

133. Rkhaila, A.; Chtouki, T.; Erguig, H.; El Haloui, N.; Ounine, K. Chemical Proprieties of Biopolymers (Chitin/Chitosan) and Their Synergic Effects with Endophytic Bacillus Species: Unlimited Applications in Agriculture. Molecules 2021, 26, 1117. [CrossRef] [PubMed]

134. Liang, X.; Duan, J.; Xu, Q.; Wei, X.; Lu, A.; Zhang, L. Ampholytic microspheres constructed from chitosan and carrageenan in alkali/urea aqueous solution for purification of various wastewater. Chem. Eng. J. 2017, 317, 766-776. [CrossRef]

135. Xu, Q.; Ji, Y.; Sun, Q.; Fu, Y.; Xu, Y.; Jin, L. Fabrication of Cellulose Nanocrystal/Chitosan Hydrogel for Controlled Drug Release. Nanomaterial 2019, 9, 253. [CrossRef] [PubMed]

136. Rop, K.; Karuku, G.N.; Mbui, D.; Michira, I.; Njomo, N. Formulation of slow release NPK fertilizer (cellulose-graftpoly(acrylamide)/nano-hydroxyapatite/soluble fertilizer) composite and evaluating its N mineralization potential. Ann. Agric. Sci. 2018, 63, 163-172. [CrossRef]

137. Ramli, R.A. Slow release fertilizer hydrogels: A review. Polym. Chem. 2019, 10, 6073-6090. [CrossRef]

138. Naz, M.Y.; Sulaiman, S.A. Slow release coating remedy for nitrogen loss from conventional urea: A review. J. Control. Release 2016, 225, 109-120. [CrossRef] [PubMed]

139. Sempeho, S.I.; Kim, H.T.; Mubofu, E.; Hilonga, A. Meticulous Overview on the Controlled Release Fertilizers. Adv. Chem. 2014, 2014, 1-16. [CrossRef]

140. Davidson, D.W.; Verma, M.S.; Gu, F.X. Controlled root targeted delivery of fertilizer using an ionically crosslinked carboxymethyl cellulose hydrogel matrix. SpringerPlus 2013, 2, 318. [CrossRef]

141. Septevani, A.A.; Rifathin, A.; Sari, A.A.; Sampora, Y.; Ariani, G.N.; Sudiyarmanto, A.; Sondari, D. Oil palm empty fruit bunch-based nanocellulose as a super-adsorbent for water remediation. Carbohydr. Polym. 2020, 229, 115433. [CrossRef]

142. Guilherme, M.R.; Aouada, F.; Fajardo, A.; Martins, A.F.; Paulino, A.; Davi, M.F.; Rubira, A.; Muniz, E. Superabsorbent hydrogels based on polysaccharides for application in agriculture as soil conditioner and nutrient carrier: A review. Eur. Polym. J. 2015, 72, 365-385. [CrossRef]

143. Ramli, R.A.; Lian, Y.M.; Nor, N.M.; Azman, N.I.Z. Synthesis, characterization, and morphology study of coco peat-graftedpoly(acrylic acid)/NPK slow release fertilizer hydrogel. J. Polym. Res. 2019, 26, 266. [CrossRef]

144. Zhang, X.; Liu, Y.; Lu, P.; Zhang, M. Preparation and properties of hydrogel based on sawdust cellulose for environmentally friendly slow release fertilizers. Green Process. Synth. 2020, 9, 139-152. [CrossRef]

145. Olad, A.; Zebhi, H.; Salari, D.; Mirmohseni, A.; Tabar, A.R. Water retention and slow release studies of a salep-based hydrogel nanocomposite reinforced with montmorillonite clay. N. J. Chem. 2018, 42, 2758-2766. [CrossRef]

146. Li, X.; Li, Q.; Xu, X.; Su, Y.; Yue, Q.; Gao, B. Characterization, swelling and slow-release properties of a new controlled release fertilizer based on wheat straw cellulose hydrogel. J. Taiwan Inst. Chem. Eng. 2016, 60, 564-572. [CrossRef]

147. Aini, A.K.; Hamzah, R.; Noriman, N.Z.; AlRashdi, A.; Johari, I.; Razlan, Z.M.; Shahriman, A.B.; Zunaidi, I.; Khairunizam, W. Slow Release Fertilizer from Treated Rice Straw/Urea Beads Coated With Natural Rubber: FTIR and UV-Vis Analysis. IOP Conf. Ser. Mater. Sci. Eng. 2019, 557, 012068. [CrossRef]

148. Rashidzadeh, A.; Olad, A. Slow-released NPK fertilizer encapsulated by NaAlg-g-poly(AA-co-AAm)/MMT superabsorbent nanocomposite. Carbohydr. Polym. 2014, 114, 269-278. [CrossRef]

149. He, Y.; Wu, Z.; Tu, L.; Han, Y.; Zhang, G.; Li, C. Encapsulation and characterization of slow-release microbial fertilizer from the composites of bentonite and alginate. Appl. Clay Sci. 2015, 109, 68-75. [CrossRef]

150. Wu, Z.; He, Y.; Chen, L.; Han, Y.; Li, C. Characterization of Raoultella planticola Rs-2 microcapsule prepared with a blend of alginate and starch and its release behavior. Carbohydr. Polym. 2014, 110, 259-267. [CrossRef] [PubMed]

151. Shi, P.; Abbah, S.A.; Saran, K.; Zhang, Y.; Li, J.; Wong, H.-K.; Goh, J.C.H. Silk Fibroin-Based Complex Particles with Bioactive Encrustation for Bone Morphogenetic Protein 2 Delivery. Biomacromolecules 2013, 14, 4465-4474. [CrossRef] [PubMed]

152. Mohammadi-Khoo, S.; Moghadam, P.N.; Fareghi, A.R.; Movagharnezhad, N. Synthesis of a cellulose-based hydrogel network: Characterization and study of urea fertilizer slow release. J. Appl. Polym. Sci. 2016, 133, 1-9. [CrossRef]

153. Olad, A.; Zebhi, H.; Salari, D.; Mirmohseni, A.; Tabar, A.R. Slow-release NPK fertilizer encapsulated by carboxymethyl cellulosebased nanocomposite with the function of water retention in soil. Mater. Sci. Eng. C 2018, 90, 333-340. [CrossRef] [PubMed]

154. El Sayed, A.M.; El-Gamal, S.; Morsi, W.M.; Mohammed, G. Effect of PVA and copper oxide nanoparticles on the structural, optical, and electrical properties of carboxymethyl cellulose films. J. Mater. Sci. 2015, 50, 4717-4728. [CrossRef]

155. Nayan, N.H.M.; Hamzah, M.S.A.; Tahir, A.A.-H.M.; Rajali, A.A.A.; Muslih, E.F.; Mazlan, R. Development of Polyvinyl Alcohol/Chitosan Hydrogel Loaded with Fertilizer Compound: Preparation, Properties and Effect on Seed Germination. J. Sci. Technol. 2018, 10, 21-27. [CrossRef]

156. Kasirajan, S.; Ngouajio, M. Polyethylene and biodegradable mulches for agricultural applications: A review. Agron. Sustain. Dev. 2012, 32, 501-529. [CrossRef] 
157. Zribi, W.; Aragüés, R.; Medina, E.; Faci, J. Efficiency of inorganic and organic mulching materials for soil evaporation control. Soil Tillage Res. 2015, 148, 40-45. [CrossRef]

158. Kader, A.; Senge, M.; Mojid, M.; Ito, K. Recent advances in mulching materials and methods for modifying soil environment. Soil Tillage Res. 2017, 168, 155-166. [CrossRef]

159. Bandopadhyay, S.; Martin-Closas, L.; Pelacho, A.; Debruyn, J.M. Biodegradable Plastic Mulch Films: Impacts on Soil Microbial Communities and Ecosystem Functions. Front. Microbiol. 2018, 9, 819. [CrossRef]

160. Chen, L.; Dai, R.; Shan, Z.; Chen, H. Fabrication and characterization of one high-hygroscopicity liquid starch-based mulching materials for facilitating the growth of plant. Carbohydr. Polym. 2020, 230, 115582. [CrossRef]

161. Zhang, M.; Dong, B.; Qiao, Y.; Yang, H.; Wang, Y.; Liu, M. Effects of sub-soil plastic film mulch on soil water and salt content and water utilization by winter wheat under different soil salinities. Field Crop. Res. 2018, 225, 130-140. [CrossRef]

162. Sun, T.; Li, G.; Ning, T.-Y.; Zhang, Z.-M.; Mi, Q.-H.; Lal, R. Suitability of mulching with biodegradable film to moderate soil temperature and moisture and to increase photosynthesis and yield in peanut. Agric. Water Manag. 2018, 208, 214-223. [CrossRef]

163. Gang, X.; Huabing, L.; Yufu, P.; Tiezhao, Y.; Xi, Y.; Shixiao, X. Plastic film mulching combined with nutrient management to improve water use efficiency, production of rain-fed maize and economic returns in semi-arid regions. Field Crop. Res. 2019, 231, 30-39. [CrossRef]

164. Kader, M.A.; Singha, A.; Begum, M.A.; Jewel, A.; Khan, F.H.; Khan, N.I. Mulching as water-saving technique in dryland agriculture: Review article. Bull. Natl. Res. Cent. 2019, 43, 1-6. [CrossRef]

165. Chopra, M.; Koul, B. Comparative assessment of different types of mulching in various crops: A review. Plant Arch. 2020, 20, $1620-1626$.

166. Sivakumar, D.; Jifon, J. Influence of Photoselective Shade Nettings on Postharvest Quality of Vegetables; Elsevier Inc.: Philadelphia, PA, USA, 2018; pp. 121-138.

167. Briassoulis, D.; Mistriotis, A.; Eleftherakis, D. Mechanical behaviour and properties of agricultural nets-Part I: Testing methods for agricultural nets. Polym. Test 2007, 26, 822-832. [CrossRef]

168. Scarascia-Mugnozza, G.; Sica, C.; Russo, G. Plastic materials in European agriculture: Actual use and perspectives. J. Agric. Eng. 2012, 42, 15-28. [CrossRef]

169. Castellano, S.; Mugnozza, G.S.; Russo, G.; Briassoulis, D.; Mistriotis, A.; Hemming, S.; Waaijenberg, D. Plastic nets in agriculture: A general review of types and applications. Appl. Eng. Agric. 2008, 24, 799-808. [CrossRef]

170. Divya, V.; Sarkar, N. Plastic Mulch Pollution and Introduction of Biodegradable Plastic Mulches-A Review. Agric. Rev. 2019, 40, 314-318. [CrossRef]

171. Ghimire, S.; Scheenstra, E.; Miles, C.A. Soil-biodegradable Mulches for Growth, Yield, and Quality of Sweet Corn in a Mediterranean-type Climate. HortScience 2020, 55, 317-325. [CrossRef]

172. Cirujeda, A.; Aibar, J.; Anzalone, Á.; Martin-Closas, L.; Meco, R.; Moreno, M.M.; Pardo, A.; Pelacho, A.; Rojo, F.; Royo-Esnal, A.; et al. Biodegradable mulch instead of polyethylene for weed control of processing tomato production. Agron. Sustain. Dev. 2012, 32, 889-897. [CrossRef]

173. Cao, L.; Liu, C.; Zou, D.; Zhang, S.; Chen, Y. Using cellulose nanocrystals as sustainable additive to enhance mechanical and shape memory properties of PLA/ENR thermoplastic vulcanizates. Carbohydr. Polym. 2020, 230, 115618. [CrossRef]

174. Zhang, M.; Zhang, L.; Tian, H.; Lu, A. Universal preparation of cellulose-based colorimetric sensor for heavy metal ion detection. Carbohydr. Polym. 2020, 236, 116037. [CrossRef]

175. Soni, B.; Hassan, E.B.; Schilling, M.W.; Mahmoud, B. Transparent bionanocomposite films based on chitosan and TEMPO-oxidized cellulose nanofibers with enhanced mechanical and barrier properties. Carbohydr. Polym. 2016, 151, 779-789. [CrossRef]

176. Ning, R.; Liang, J.; Sun, Z.; Liu, X.; Sun, W. Preparation and characterization of black biodegradable mulch films from multiple biomass materials. Polym. Degrad. Stab. 2021, 183, 109411. [CrossRef]

177. Mendonça, S.R.; Ávila, M.C.R.; Vital, R.G.; Evangelista, Z.R.; Pontes, N.D.C.; Nascimento, A.D.R. The effect of different mulching on tomato development and yield. Sci. Hortic. 2021, 275, 109657. [CrossRef]

178. Sarkar, D.; Solaiman, A.H.M.; Jahan, M.S.; Rojoni, R.N.; Kabir, K.; Hasanuzzaman, M. Soil parameters, onion growth, physiology, biochemical and mineral nutrient composition in response to colored polythene film mulches. Ann. Agric. Sci. 2019, 64, 63-70. [CrossRef]

179. Franquera, E.N.; Mabesa, R.C. Colored Plastic Mulch Effects on the Yield of Lettuce (Lactuca sativa L.) and Soil Temperature. J. Adv. Agric. Technol. 2016, 3, 155-159. [CrossRef]

180. Sintim, H.Y.; Bary, A.I.; Hayes, D.G.; Wadsworth, L.C.; Anunciado, M.B.; English, M.E.; Bandopadhyay, S.; Schaeffer, S.M.; DeBruyn, J.; Miles, C.A.; et al. In situ degradation of biodegradable plastic mulch films in compost and agricultural soils. Sci. Total. Environ. 2020, 727, 138668. [CrossRef]

181. Yang, Y.; Li, P.; Jiao, J.; Yang, Z.; Lv, M.; Li, Y.; Zhou, C.; Wang, C.; He, Z.; Liu, Y.; et al. Renewable sourced biodegradable mulches and their environment impact. Sci. Hortic. 2020, 268, 109375. [CrossRef]

182. Gupta, G.S. Land Degradation and Challenges of Food Security. Rev. Eur. Stud. 2019, 11, p63. [CrossRef]

183. Chae, Y.; An, Y.-J. Current research trends on plastic pollution and ecological impacts on the soil ecosystem: A review. Environ. Pollut. 2018, 240, 387-395. [CrossRef] [PubMed]

184. Abhilash, M.; Thomas, D. Biopolymers for biocomposites and chemical sensor applications. In Biopolymer Composites in Electronics; Elsevier Inc.: Philadelphia, PA, USA, 2017; pp. 405-435. [CrossRef] 
185. Schaude, C.; Meindl, C.; Fröhlich, E.; Attard, J.; Mohr, G.J. Developing a sensor layer for the optical detection of amines during food spoilage. Talanta 2017, 170, 481-487. [CrossRef] [PubMed]

186. Shahi, N.; Joshi, G.; Min, B. Effect of Regenerated Cellulose Fibers Derived from Black Oat on Functional Properties of PVA-Based Biocomposite Film. Processes 2020, 8, 1149. [CrossRef]

187. Brinkhoff, J.; Hornbuckle, J.; Dowling, T. Multisensor Capacitance Probes for Simultaneously Monitoring Rice Field Soil-WaterCrop-Ambient Conditions. Sensors 2017, 18, 53. [CrossRef] [PubMed]

188. Wang, Y.; Zhang, L.; Zhou, J.; Lu, A. Flexible and Transparent Cellulose-Based Ionic Film as a Humidity Sensor. ACS Appl. Mater. Interfaces 2020, 12, 7631-7638. [CrossRef] [PubMed] 